Rev. Ivan BODROŽIĆ Vanda KRAFT SOIĆ*

\title{
HERETICAL DOCTRINE OF PHOTINUS OF SIRMIUM IN HILARY OF POITIERS' DE TRINITATE
}

The bishop Photinus, known as Photinus of Sirmium, came from Ancyra in Galatia. He was a deacon and a disciple of Marcellus of Ancyra ${ }^{1}$. He became the bishop of Sirmium probably in late 343 or early $344^{2}$. Jerome reported that he had written many works, but none of them have been preserved ${ }^{3}$. Photinus was condemned at Antioch (Ekthesis Makrostichos, 344 ${ }^{4}$ ), and again at the Councils held in Milan, in the year 345 and $347^{5}$, but he was finally deposed and sent to exile by the Council of Sirmium in the year $351^{6}$. The Council promulgated the Creed and attached to it twenty-seven Anathemas directed

${ }^{*}$ Rev. Prof. dr Ivan Bodrožić - Head of Department of History of Christian Literature and Christian Doctrine at the Catholic Faculty of Theology, University of Zagreb, Croatia; e-mail: ivan. bodrozic@gmail.com; Dr Vanda Kraft Soić - Senior Instructor at the Department of History of Christian Literature and Christian Doctrine at the Catholic Faculty of Theology, University of Zagreb, Croatia; e-mail: kraftsoicv@kbf.hr.

${ }^{1}$ Cf. G. Bardy, Photin de Sirmium, DThC XII/2, 1532 (based on Athanasius, De synodis 26, PG 26, 732; Socrates, HE II 18, PG 67, 224; Hieronymus, De viris illustribus 107, PL 23, 703; Hilarius Pictaviensis, Fragmenta historica 2, 19, PL 10, 645); M. Simonetti, Fotino di Sirmio, NDPAC II 1998; R.P.C. Hanson, The Search for the Christian Doctrine of God. The Arian Controversy (318386), Grand Rapids (MI) 2007², 236. However, Marcellus' influence on Photinus is still questionable, cf. ibidem; D.H. Williams, Monarchianism and Photinus of Sirmium as the Persistent Heretical Face of the Fourth Century, HTR 99 (2006) 196-197; Bardy, Photin de Sirmium, p. 1534.

${ }^{2}$ Cf. Bardy, Photin de Sirmium, p. 1532.

${ }^{3}$ Cf. ibidem, based on Hieronymus, De viris illustribus 107.

${ }^{4}$ Creed in: Athanasius, De synodis 26, PG 26, 728ff; Socrates, HE 2, 19, PG 67, 224ff; text in Hahn, Bibliothek der Symbole und Glaubensregeln der Alten Kirche, Breslau 1897, 192-196. M. Simonetti (Studi sull'arianesimo, Rome 1965, 138, n. 23) commented that Photinus has seemingly been mentioned for the first time in c. 5 and 6 of that Creed. D.H. Williams (Monarchianism and Photinus of Sirmium, p. 199) claims that Photinus was condemned for the fist time by name in Ekthesis Makrostichos.

${ }^{5}$ D.H. Williams (Monarchianism and Photinus of Sirmium, p. 199) refers to the Council in Milan, held in 345, and (based on Hilarius Pictaviensis, Collectanea Antiariana Parisina, B 2, 7, ed. A. Feder, CSEL 65, Vindobonae 1916, 145) the Council held in Rome in 347. Also, Ch. Beckwith (Hilary of Poitiers on the Trinity. From "De Fide" to "De Trinitate”, New York 2008, 35).

${ }^{6}$ Cf. Bardy, Photin de Sirmium, p. 1533. 
mainly against the doctrine of Photinus that were moreover anti-Marcellan and anti-Sabellian in nature ${ }^{7}$. Photinus returned to Sirmium again at the accession of the Emperor Julian. However, he was deposed again by Valentinian and lately died in exile, in the year $376^{8}$.

Since none of his works has been preserved, his doctrine can be reviewed only on the basis of the conciliar documents and works of his opponents. The difficulties in the review of Photinus' doctrine based on De Trinitate certainly can be attributed, as already pointed out by Smulders, to the fact that Hilary provides just the basic outline of his opponents' doctrines, tries to reduce all heresies to "one capital error" and names not his living opponents ${ }^{9}$. One of the valuable sources of Photinus' doctrine is the work of Hilary of Poitiers, who was his contemporary and took part in the Trinitarian, Christological and other theological debates.

The aim of this study is to perform a comprehensive and systematic review of the Photinus' doctrine based on Hilary's work De Trinitate. To our knowledge, it has not been done so far, although De Trinitate is regularly cited as the source of Photinus' doctrine. The theological treatise ${ }^{10}$ De Trinitate, written between the year 356 and $360^{11}$, is the most important dogmatic work of Hilary of Poitiers ${ }^{12}$ and the first extensive work on the Trinity from the West ${ }^{13}$. Promoting understanding of the Trinity, Hilary deals with the Nicene Creed and the Nicene theology defending them and refuting the Arian doctrine and other anti-Nicene standpoints, particularly those from Marcellus of Ancyra and Photinus of Sirmium, distancing himself from them ${ }^{14}$.

In De Trinitate, Hilary either refers to Photinus, or identifies him with Ebion occasionally ${ }^{15}$, but naming him not throughout the Book Ten. This article deals

${ }^{7}$ Cf. Hanson, The Search for the Christian Doctrine of God, p. 328. The First Creed of Sirmium is actually the Fourth Creed of Antioch (the Dedication Council) held in 341, cf. Bardy, Photin de Sirmium, p. 1533; Williams, Monarchianism and Photinus of Sirmium, p. 200 and n. 65. J.N.D. Kelly (Early Christian Creeds, London $1976^{3}, 281$ ) refers to 26 Anathemas. Greek text in Athanasius, De synodis 27, PG 26, 736; Socrates, HE II 30, PG 67, 280ff; latin text in: Hilarius Pictaviensis, Liber de Synodis seu de Fide Orientalium 38-61, PL 10, 509-521. On the creed and the Anathemas cf. Kelly, Early Christian Creeds, p. 281-282; Simonetti, La crisi ariana nel IV secolo, Rome 1975, 203; idem, Studi sull'arianesimo, p. 135-139; Hanson, The Search for the Christian Doctrine of God, p. 326-329; Williams, Monarchianism and Photinus of Sirmium, p. 200-202.

${ }^{8}$ Cf. Bardy, Photin de Sirmium, p. 1533-1534; Hanson, The Search for the Christian Doctrine of God, p. 236.

${ }^{9}$ Cf. P. Smulders, La Doctrine trinitaire de S. Hilaire de Poitiers, Rome 1944, 91-92.

${ }^{10}$ Cf. G.M. Newlands, Hilary of Poitiers: A Study in Theological Method, Eugene (OR) 2008, 101.

${ }^{11}$ Cf. M. Figura - J. Doignon, Introduction, in: Hilarius Pictaviensis, De Trinitate, ed. G.M. de Durand - Ch. Morel - G. Pelland, SCh 443, Paris 1999, 11.

${ }^{12}$ Cf. ibidem; H.C. Brennecke, Hilarius von Poitiers, TRE XIV 318.

${ }^{13}$ Cf. Figura - Doignon, Introduction, p. 11.

${ }^{14}$ Cf. ibidem; Brennecke, Hilarius von Poitiers, p. 318; Newlands, Hilary of Poitiers, p. 101; M. Durst, Hilarius, hl. v. Poitiers, LThK V 102.

${ }^{15}$ We will use critical latin text of Hilary's De Trinitate by P. Smulders (CCL 62 and 62A) 
with the texts of De Trinitate that, according to the scholarship, focus on Photinus' doctrine.

It is known that the error of Photinus is primarily Christological, although it emerged in the context of the Trinitarian disputes ${ }^{16}$. This is also confirmed by Hilary's comments referring to Photinus' doctrine that "everything begins with Mary" 17 , since "Jesus Christ as a man with merely an ordinary soul and body had no other origin for himself except this one in which He began to be a man"18.

This article aims to explore and elaborate on Photinus' doctrine in that view. First, we will identify and analyse the subject of the Incarnation as understood by Photinus and interpreted by Hilary. Then, we will determine what was "assumed" ("taken on") of the humanity by the Word of God for the purpose of Incarnation, and in which way. Furtherly, we will analyse the direct effects of the Incarnation understood in such a way with referring to Photinus' standpoints on the unity of the Divine and human and on the Divine Sonship, according to Hilary. Finally, we will consider the claims in the scholarship according to which Photinus, motivated by soteriology, insisted on the fact that Jesus had a human soul, that is on the wholeness of his humanity.

1. The subject of the Incarnation. Interpreting Photinus' doctrine on the Incarnation, Hilary affirms that God the Word, that is, the Word of God is its subject: "God the Word, as if he were some part of the power of God, extends himself by a sort of unbroken continuity, and dwells in that man who began to exist from Mary" "19. However, based on Hilary's comment, Photinus did not understand the Word as subsisting $\operatorname{God}^{20}$, "the Word that «in the beginning was

published in: Hilaire de Poitiers, La Trinité, I-III, ed. J. Doignon - G.M. de Durand - Ch. Morel - G. Pelland, SCh 443, 448 and 462, Paris 1999-2001. Cf. Hilarius Pictaviensis, De Trinitate VII 3, 23, SCh 448, Paris 2000, 280: "Natum quoque Dei Filium ex Maria dicturo Hebion, quod est Fotinus"; ibidem VII 7, SCh 448, 290: "Hebion, qui Fotinus est".

${ }^{16}$ P. Smulders (La Doctrine trinitaire de S. Hilaire de Poitiers, p. 95) refers to Photinus' doctrine as primarily Christological; Simonetti (Studi sull'arianesimo, p. 150) claims that Christology is the central point of Photinus' doctrine. Williams (Monarchianism and Photinus of Sirmium, p. 196) argues that Photinus' theology was primarily motivated by Christological concerns, and that his opponents mostly reproched him the Christological aspect of his doctrine.

${ }^{17}$ Hilarius Pictaviensis, De Trinitate II 4, SCh 443, 280: "Omne initium ex Maria concendens". When citing Hilarius Pictaviensis, De Trinitate in English we will use the translation by S. McKenna: The Fathers of the Church 25, New York 1954.

${ }^{18}$ Ibidem X 51, ed. G.M. de Durand - Ch. Morel - G. Pelland, SCh 462, Paris 2001, 254: "Quia Christus Iesus, animae solum communis et corporis homo hoc habeat sui quo esse homo coepit exordium", transl. McKenna, p. 438.

${ }^{19}$ Ibidem X 50, SCh 462, 252-254: "Deus verbum tamquam pars aliqua virtutum Dei quodam se tractu continuationis extendens, hominem illus qui a Maria esse coepit habitaverit". The Word of God as the subject of the Incarnation will be mentioned in the following chapters: X 51, SCh 462, 254: "Hominem [...] in quo verbum Dei, ed est quaedam quasi potestas extensae vocis habitaverit", cf. also ibidem X 21-22, SCh 462, 200-206; 50-51, SCh 462, 252-254.

${ }^{20} \mathrm{Cf}$. ibidem X 21, SCh 462, 200. 
with God»" (Jn 1:1), but as a mere word, the one of God's operative, efficacious powers ${ }^{21}$ which is deprived of the pre-existence and of the Divine nature of the subsistent only-begotten Son of God, the Word of God ${ }^{22}$. The relationship of the Word understood as such and God, according to Hilary, Photinus defines through analogy between the Word and the speaker ${ }^{23}$ : by its nature, it is the utterance of the voice (prolatio vocis ${ }^{24}$, sermo vocis emissae, ${ }^{25}$ sonus vocis ${ }^{26}$ ), sound (sonus $)^{27}$, word (sermo $)^{28}$. Epiphanius' Panarion confirms this Photinus' view; his testimony is of a great value since it is based on the stenographic record of the debate held between Photinus and Basil of Ancyra at the Council of Sirmium in the year $351^{29}$. Hilary pointed out that the Word taken as such should be understood as the announcement of future events or future reality (elocutio negotiorum) or as the expression or utterance of a concealed thought (elocutio or sermo reconditae cogitationis, cogitationis eloquium), which is considered eternal only if the one who thinks is eternal ${ }^{30}$. As Manlio Simonetti notes, this

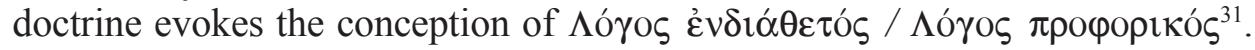
The doctrine according to which the Son is named by the internal or the uttered Word of God is condemned by the Anathema no. 8 at the Council of Sirmium in the year $351^{32}$. However, for Photinus in both cases the thought or the Word

${ }^{21}$ Cf. ibidem VII 11, SCh 448, 298: "internae potestatis aut sensus efficax motus".

${ }^{22}$ Cf. ibidem II 4, SCh 443, 280: "Neque subsistens antea quod «in principio apud Deum erat Deus verbum» virgo susceperit, sed carnem genuerit per verbum: quia in verbo antea, non existentis unigeniti Dei naturam dicat"; X 21, SCh 462, 200: "Sed volentes unigenitum Deum, qui in principio apud Deum erat Deus verbum, non substantivum Deum esse".

${ }^{23}$ Cf. ibidem X 21, SCh 462, 200-202: "Ut loquentibus est suum verbum, hoc sit Patri Deo Filius". It is to point out that Hilary identifies the Son and the Word.

${ }^{24}$ Cf. ibidem VII 11, SCh 448, 296.

${ }^{25}$ Cf. ibidem X 21, SCh 462, 200.

${ }^{26}$ Cf. ibidem II 4, SCh 443, 280; II 15, SCh 443, 300.

${ }^{27}$ Cf. ibidem II 15, SCh 443, 302.

${ }^{28} \mathrm{Cf}$. ibidem.

${ }^{29}$ Cf. Epiphanius, Panarion 71, 2, PG 42, 376D - 377B, transl. F. Williams, The Panarion of Epiphanius of Salamis, Books II and III. De Fide, Leiden - Boston 201322, 429; 71, 3, PG 42, 377B - 380A, transl. Williams, p. 431; 71, 4, PG 42, 380A-D, transl. Williams, p. 431; 71, 5, PG 42, 380D - 381B, transl. Williams, p. 432. The stenographic record of the debate held between Photinus and Basil of Ancyra at the Council of Sirmium in 351, is taken as a primary source, cf. Williams, The Panarion of Epiphanius of Salamis, p. 428, n. 1. In his study on Photinus' doctrine, Simonetti (Studi sull'arianesimo, p. 135) takes Epiphanius' testimony as a criterion of consistency when dealing with other resources reffering to Photinus' doctrine.

${ }^{30}$ Cf. Hilarius Pictaviensis, De Trinitate II 15, SCh 443, 300. Hanson (The Search for the Christian Doctrine of God, p. 237) also points on the analogy between the Man and thought in Photinus' speculation.

${ }^{31}$ For a more thorough analysis of the subject, consult Simonetti, Studi sull'arianesimo, p. 146147. Simonetti points to the fact that Ekthesis Makhrostichos ascribes this doctrine to Marcellus and Photinus, cf. ibidem, p. 138.

${ }^{32}$ Concilium Sirmiense (351) Anathematismi 8, ed. in: SCL 1, Kraków 2006, 202: "Si quis

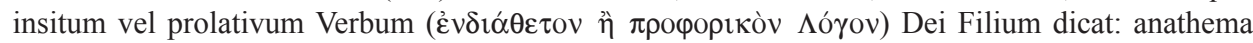


remains impersonal and non-subsistent ${ }^{33}$. That standpoint according to Hilary seems to result from an unacceptable interpretation of Jn 1:1 where apud Deum is understood as in Deo ${ }^{34}$. Commenting Sirmian Anathema no. 8. in De synodis 46 , Hilary observes that heretics exclude the existence of the Son, claiming that it is "only the word, going forth as an utterance from the speaker's lips" or "the unembodied sound of an impersonal "voice" and the Son is "resembling any word we utter in virtue of our inborn power of speaking". According to such claim "God the Word, who was in the beginning with God, is only the word of a voice sometimes internal and sometimes expressed" 35 . Understood in this way, according to De Trinitate, the Word corresponds to something that is semper internum to someone ${ }^{36}$, i.e. without subsistence, the "efficacious movement of entirely internal power or thought" ${ }^{37}$.

In order to have a better understanding of Photinus' subject of the Incarnation, the Word, we have to refer to Hilary's text at the beginning of this passage $^{38}$. We note that Hillary refers to the Word, the subject of the Incarnation, as "a part of" (pars, $\mu$ ćpos) $)^{39}$. According to Hilary, Photinus understood the

sit"; Hilarius Pictaviensis, Liber de synodis seu de fide orientalium 45, PL 10, 514. Epiphanius ascribes this notion to Photinus, cf. Epiphanius, Panarion 71, 3-4, PG 42, 377B - 380D, transl. Williams, p. 431, which is also suggested by Simonetti (Studi sull'arianesimo, p. 138. 146); Simonetti (ibidem, p. 138) reports that Eusebius of Caesarea censured Marcellus for the speculation based on such scheme, and claims that Photinus in some way had to take it into account, although it does not mean that any of them used mentioned expressions. In Liber de synodis seu de fide orientalium 46 (PL 10,515) it seems that Hilary interprets the Sirmian Anathema according to Photinus' doctrine.

${ }^{33}$ Simonetti (Studi sull'arianesimo, p. 145) came to the same cnclusion based on all available sources, as well as Smulders (La doctrine trinitaire de S. Hilaire de Poitiers, p. 96) whose views are based on the complete works of Hilary.

${ }^{34}$ Cf. Hilarius Pictaviensis, De Trinitate II 15, SCh 448, 300-302: "Nam etsi sententiam primam rudis auditor amiseras: «In principio erat verbum», de sequenti quid quaereris: Et «verbum erat apud deum»? Numquid audieras «in Deo», ut sermonem reconditae cogitationi acciperes? Aut fefellerat rusticum, quid esset inter inesse et adesse momenti? Id enim quod «in principio erat» non in altero esse sed cum altero praedicatur". Cf. the same testimony by Epiphanius of Salamis ( $\mathrm{Pa}$ narion 71, 4, PG 42, 380A-D, transl. Williams, p. 431); testimony also in Nestorius, cf. Simonetti, Studi sull'arianesimo, p. 146. On Ambrosiaster's criticism of the Photinian exegesis of Jn 1:1 cf. L.A. Speller, New Light on the Phoitinians: the Evidence of Ambrosiaster, ThS 34 (1983) 111-112.

${ }^{35}$ Hilarius Pictaviensis, Liber de Synodis seu de Fide Orientalium 46, PL 10, 515: "Haeretici perimentes, quantum in ipsis est, Dei filium, verbum esse tantum confitentur, prodeuntem scilicet loquentis ore sermonem, et insubstantivae vocis incorporalem sonum: ut Deo patri istius modi sit verbum Filius, cuiusmodi per insitam nobis loquendi naturam verbum omne profertur in vocem. Fraus ergo haec omnis in damnatione est: quae Deum Verbum, quod in principio apud Deum erat, tanquam verbum esse insitae ac prolatae vocis affirmet", transl. E.W. Watson - L. Pullan - K. Knight: St. Hilary of Poitiers, On the Councils, NPNF Ser. II, vol. 9, Buffalo (NY) 1899, 17.

${ }^{36} \mathrm{Cf}$. idem, De Trinitate VII 11, SCh 448, 298.

${ }^{37}$ Ibidem VII 11, SCh 448, 298 and infra, n. 21: "Internae potestatis aut sensus efficax motus".

${ }^{38} \mathrm{Cf}$. ibidem X 50, SCh 462, 252-254 and infra, n. 19: "Deus verbum tamquam pars aliqua virtutum Dei quodam se tractu continuationis extendens, hominem illus qui a Maria esse coepit habitaverit".

${ }^{39}$ Understanding according to which the only-begotten Son is just a part (de portione) of the 
Word ultimately only as a part of God's powers (pars virtutum $)^{40}$ - such as the thought or speech, respectively. For the purpose of economy of the Incarnation, this part of the powers extends in order to in/dwell in a man who was born of Mary. In the following passage, presenting the same Photinus' claim, instead of the term extensio Hilary uses the term protensio, which he also uses to expound Marcellus' doctrine of the Incarnation ${ }^{41}$. Such teaching could be related to Sirmian Anathemas no. 6 and no. 7, which condemn the one who claims that the substance of God extends and contracts (no. 6), and the one who claims that the Son is the substance of God extended or that the Son is the extension of God's substance (no. 7) ${ }^{42}$. Commenting on latter in the De synodis 45 , Hilary points out that the original intention of the concept of the extension and contraction was to teach the immutability of God (indemutabilem Deum), however, it resulted in heresy, according to which:

"the Unborn God by expansion of His substance extended Himself as far as the holy Virgin, in order that this extension produced by the increase of His nature and assuming manhood might be called Son"43.

Hilary concludes that on the one hand this understanding excludes that the Son is begotten of the Father, and on the other hand, contradicting the primary

Father is condemned by Hilary in for. ex. ibidem II 8, SCh 443, 290-292, claiming that the Son is the perfect from the perfect, for he who has all, has given all to Him. Hilary refers to Jn 16:15; 17:10 and Col 2:9: "Quia in ipso inhabitat omnis plenitudo divinitatis corporaliter".

${ }^{40}$ In ibidem X 51 the Word of God will be mentioned again as one of God's powers (power of speech): the Word of God dwells in man "quaedam quasi potestas extensae uocis habitaverit". Simonetti (Studi sull'arianesimo, p. 145-146) analysing Photinus' doctrine, came to the conclu-

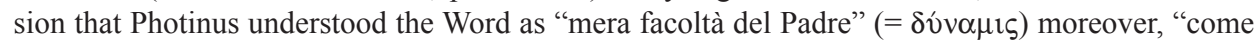
un modo di manifestarsi del Padre nell'economia del creato". Smulders (La doctrine trinitaire de S. Hilaire de Poitiers, p. 96), based on Hilary's work, concluded that Photinus understod the Word as "une vertue divine".

${ }^{41}$ Cf. Hilarius Pictaviensis, De Trinitate X 51, SCh 462, 254: "Christus Iesus [...] quem estrinsecus protensi sermonis potestas [...] confirmaverit". On Marcellus' doctrine hidden under the name of Sabelius cf. ibidem I 16. The attached note indicates to the places in De Trinitate where protendo/extendo are mentioned. According to Claudio Moreschini (Il linguaggio teologico di Ilario di Poitiers, SC 103 (1975) 338) term extensio does not significantly differ from the term protensio.

${ }^{42}$ Cf. Concilium Sirmiense (351) Anathematismi 6, SCL 1, 202: "Si quis dilatatam substantiam Dei Filium dicat facere ( $\pi \lambda \alpha \tau \hat{v} v \varepsilon \sigma \theta \alpha \imath)$ et contrahi $(\sigma v \sigma \tau \varepsilon \dot{\lambda} \lambda \lambda \varepsilon \sigma \theta \alpha \imath)$ dicit: anathema sit". According to Simonetti (Studi sull'arianesimo, p. 136 and n. 8) the Anathemas no.6 and no.7 are primarily directed against Marcellus, but it does not mean that they are not also directed against Photinus' standpoints; Concilium Sirmiense (351) Anathematismi 7, SCL 1, 202: "Si quis dilatatam substantiam (ov̉oíav) Dei Filium dicat facere, aut latitudinem ( $\pi \lambda \alpha \tau v \sigma \mu$ òv) substantiae eius, sicut sibi videtur Filium nominet: anathema sit". Cf. also Hilarius Pictaviensis, Liber de Synodis seu de Fide Orientalium 45, PL 10, 514.

${ }^{43}$ Hilarius Pictaviensis, Liber de Synodis seu de Fide Orientalium 45, PL 10, 514-515: "Quidam enim ausi sunt innascibilem Deum usque ad sanctam Virgine substantiae dilatatione protendere: ut latitudo deducta quodam naturae suae tractu assumensque hominem filius nuncuparetur", NPNF Ser. II, vol. 9, 17. The concept of extension was also rejected as materialistic by Arians, cf. idem, De Trinitate VI 17, SCh 448, 202. 
intention, it presumes the Father's mutability ${ }^{44}$. Hilary explains that the contraction and extension (contrahi et dilatari) involve physical affections (passio), which implies a change (demutatio) of God's substance, thus inappropriate to incorporeal $\mathrm{God}^{45}$. In De Trinitate Hilary also condemns interpretation according to which the Son originates from the Father by extention (dilatatio), opposing to it the fullness of the Godhead immanent to the Son by his generation of the Father ${ }^{46}$. According to Hilary, extension (extensio), like series and fluxus, and like analogies between springs and streams, trees and branches, fire and heat, does not express the unity of the Father and the Son in an adequate way, since

"These objects are inseparable extension (protensio) of themselves and bound together rather than existing by themselves [...] And this thing itself is alone by itself rather than a thing that has received its being from the existing thing" ${ }^{\prime 47}$.

At the beginning of the passage, we saw that Hilary refers to extensio as to "a sort of unbroken continuity" 48 . The Monarchial position, according to which Mary gave birth to the Unborn God or a part of him is condemned by the Anathema no. 4 at the Council of Sirmium ${ }^{49}$. In De synodis Hilary explains that this Anathema is pronounced against heretics to deprive them of opportunity to declare that the Unborn God, or a part of Him, was born of Mary, and to open the door to heresy since the fact of the essence is declared to be one in the Father and the Son having one name on account of the exact similarity of their natural essence. This fact is not to be understood as the Person of the begotten essence is repudiated, that is as the substance of God is singular and undifferentiated because one name for the essence of each is predicated, that is, one $\operatorname{God}^{50}$.

${ }^{44}$ Cf. idem, Liber de Synodis seu de Fide Orientalium 45, PL 10, 515.

${ }^{45} \mathrm{Cf}$. ibidem 44, PL 10, 514, commenting on the Sirmian Anathema no.6: "Contrahi et dilatari corporalis est passio: Deus autem, qui spiritus est, et spirat ubi vult, non se per demutationem substantiae aut dilatat, aut contrahit. Extra corporalis enim naturae necessitatem liber manens, quod vult, et cum vult, et ubi vult, id praestat ex sese. Impium ergo est substantiae demutationem libertati tantae virtutis adscribere". More on the movement of dilation and contraction of God's substance in Photinus' thought cf. Williams, Monarchianism and Photinus of Sirmium, p. 201-202. Williams (ibidem, p. 202) concludes that due to these concepts Photinus' contemporaries called him 'theological successor" of Paul Samosata, Sabellius, and even Ebion.

${ }^{46}$ Cf. Hilarius Pictaviensis, De Trinitate III 17, SCh 448, 366, and infra, n. 39.

${ }^{47}$ Ibidem IX 37, SCh 462, 88: "Haec enim a se inseparabili protensione manent potius detenta, quam sibi sunt $[\ldots]$ Et haec ipsa res rola sibi potius, quam res ex re substituta est", transl. McKenna, p. 357.

${ }^{48} \mathrm{Cf}$. ibidem X 50, SCh 462, 252-254, text of the n. 16.

${ }^{49}$ Cf. Concilium Sirmiense (351) Anathematismi 4, SCL 1, 202: "Et si quis innascibilem

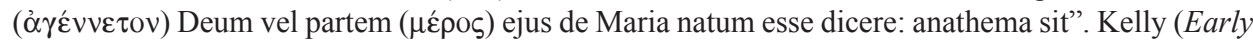
Christian Creeds, p. 281) claims that Marcellus and Photinus' views are condemned by this Anathema; Simonetti (Studi sull'arianesimo, p. 137) states that at least Anathemas from no. 4 to no. 18 can be considered as directed against Marcellus and Photinus.

${ }^{50}$ Cf. Hilarius Pictaviensis, Liber de Synodis seu de Fide Orientalium 42, PL 10, 513-514: "Ne 
It is to conclude that Photinus' doctrine excludes that the Son of God/God the Word is begotten of the Father ${ }^{51}$. The Word thus interpreted by Photinus, according to Hilary, cannot be attributed the word "God" in accordance to Jn 1:1, "the Word was God", to Photinus' view the term "to be" in Jn 1:1 was understood as an accidental ${ }^{52}$. In brief, Photinus' understanding of the concept of the Word - which is denied by heretic not only its subsistence but also its very existence - taken from Hilary's criticism:

"Here is the Word's meaning and its name: and the Word was God. Nothing is said about the utterance of the voice and expressing of thoughts! This word is a thing, reality (res) not sound (sonus), nature (natura), not word (sermo), God, not inanition (inanitas)" ${ }^{\prime 53}$.

Hilary identifies the Word as God but it does not mean that it can be identified with God the Father: "Since it is «with God» nihil nec offenditur nec infertur" 54 .

We can agree with M. Simonetti - who on the basis of all available sources confirmed important Photinus' positions stated herein - that the Word understood in this way can ultimately be identified with the Father ${ }^{55}$. The Word is,

quod nuncupatae essentiae in Patre et Filio, per indissimilem naturam, nomen unum est, occasionem haereticis praestaret, ut innascibilem Deum, vel partem eius, nasci de Maria praedicarent; occursum est salutaris definitione sententiae, ut anathema esset hoc confitens. Non enim religiosa unitas nominis, ex indifferentis naturae essentia constituta, personam genitae ademit essentiae, ut unici ac singularis Dei substantia per unionem nominis intelligatur: cum utriusque essentiae nomen unum, id est, Deus unus, ob indiscretae in utroque naturae indissimilem substantiam praedicetur".

${ }^{51}$ Simonetti (Studi sull'arianesimo, p. 148) and Hanson (The Search for the Christian Doctrine of God, p. 237), on the basis of all available sources, conclude that the generation of the Son is excluded.

${ }_{52}$ Condemning Photinus' doctrine which denies the subsistence of the Son, in De Trinitate VII 11, SCh 448, 298: "Deus igitur qui est, non est aliud quam Deus. Nam eum audio «et Deus erat uerbum», non dictum solum audio uerbum Deum, sed demonstratum intellego esse quod Deus est, quia sicut superius in Moyse deo et in cognominatis diis per appellationem nomen adiectum sit, hic autem res significata substantiae est, cum dicitur: «Deus erat». Esse enim non est accidens nomen, sed subsistens ueritas et manens causa et naturalis generis proprietas".

${ }^{53}$ Ibidem II 15, SCh 443, 302: "Statum uerbi et nomen expecta. Dicit namque: «Et Deus erat uerbum». Cessat sonus uocis et cogitationis eloquium. Verbum hoc res est, non sonus; natura, non sermo; Deus, non inanitas est", transl. McKenna, p. 47-48 (we have altered the last word of the citation from "voice" into "inanition"). Cf. also ibidem II 16, SCh 443, 302-304. According to Hilary, the Word, that is, the Son receives his subsistence, his reality (as God of God), his essence, by his generation from the Father, due to which they are identical in nature, cf. ibidem VII 11, SCh 448, 296-298.

${ }^{54}$ Ibidem II 16, SCh 443, 304.

${ }^{55}$ Cf. Simonetti, Studi sull'arianesimo, p. 146. Simonetti refers to Nestorius (Sermo 12, 13, PL 48, 856) who reported that Photinus sometimes named Logos by name of the Logos, sometimes

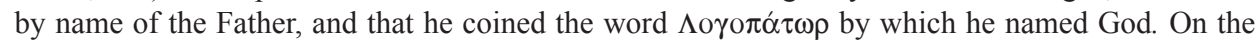
basis of his own interpretation of Jn 1:1, which primarily reads that the Word was with God, and then that the Word was God, Photinus would have concluded that John "Deum Verbum aliquando Deum aliquando Verbum appellat, tamquam extentum atque collectum", as quoted by Simonetti, Studi sull'arianesimo, p. 146, reffering to Loofs (Leitfaden zum Studium der Dogmengeschichte, 
according to M. Simonetti, "God the Father in his manifestation, through his activity, in the created world, especially in the world of people" ${ }^{n 6}$.

According to such conception, which excludes subsistence of the Son, Hilary inferred that God is to be considered alone/solitary (solum $)^{57}$, which is a rigid Monarchianism.

2. What was "assumed" (taken on) of the humanity by the Word of God for the purpose of Incarnation, and in which way? In the Book Two of De Trinitate (II 4), presenting Photinus' doctrine - and attributing it to the fictional Ebion ${ }^{58}$ - Hilary states that the Virgin "brought forth flesh through the word (per verbum)" ${ }^{\prime 59}$ and, as it has already been stated, it is not matter of subsistent God the Word. However, Hilary's explanation points to a supernatural intervention, the Virginal conception of Jesus ${ }^{60}$. According to Epiphanius, Photinus taught that Christ was conceived by the Holy Spirit and born of the Virgin Mary ${ }^{61}$.

Photinus' doctrine referring to the non-subsistent Word of God which is a mere sermo vocis emissae $e^{62}$ and his doctrines referring to the man born of the Virgin and indwelt by the Word of God like a prophet by the Spirit and to two subjects as a result of Incarnation which are found in De Trinitate X 21

p. 196) who emphasizes that these words are only unique and authentic Photinus' words that have been preserved.

${ }^{56}$ Cf. Simonetti, Studi sull'arianiesimo, p. 147-148: "Il Logos per Fotino altro non è se non Dio Padre considerato nel suo manifestarsi, con la sua azione, al mondo creato, particolarmente al mondo degli uomini". This claim is supported by Hanson (The Search for the Christian Doctrine of God, p. 237): "Logos for him was simply a mode of manifestation of the Father, a power or aspect of him not in any serious sense distinct from him", based on all available sources.

${ }^{57}$ Cf. Hilarius Pictaviensis, De Trinitate VII 3, SCh 448, 282; IX 37, SCh 462, 88. Simonetti argues that (Studi sull'arianesimo, p. 145) this rigid monotheism is based on Is 44:6s. as a starting point of Photinus' reflection, which is supported by Hanson (The Search for the Christian doctrine of God, p. 237).

${ }^{58}$ Cf. A.F.J. Klijn, Ebioniti, NDPAC I 1523-1524.

${ }^{59}$ Hilarius Pictaviensis, De Trinitate II 4, SCh 443, 280: "Virgo [...] carnem genuerit per verbum: quia in verbo antea, non existentis unigeniti Dei naturam dicat, sed sonum vocis elatum", transl. McKenna, p. 37.

${ }^{60}$ Smulders (La doctrine trinitaire de S. Hilaire de Poitiers, p. 96) refers to the above text to conclude that Photinus claims that the Virgin Mary would conceive and bear a man, who would be called the Son and the Word of God because of that origin. This report of the bishop of Poitiers who was contemporary of Photinus and a connoisseur of heresy is, according to Smulders, a reliable source for the debates on Photinus' doctrine on Virginal Conception. Simonetti (Studi sull'arianesimo, p. 151 and n. 86 and 87) asserts that Photinus taught the miraculousness of the Virginal coneption of Jesus referring to Epiphanius Salamiensis, Panarion 71, 1, and points out that only Pseudo-Mercator held that Jesus' conception occurred naturally by Joseph and Mary, which is also supported by Bardy, Photin de Sirmium, p. 1534.

${ }^{61}$ Cf. Epiphanius Salamiensis, Panarion 71, 1; 71, 2; as referring to Epiphanius' testimony (ibidem 71, 1; 71, 2), to Photinus, the Holy Spirit is greater than Christ.

${ }^{62}$ Cf. Hilarius Pictaviensis, De Trinitate X 21, SCh 462, 200. 
and 22 (will be discussed lately) ${ }^{63}$, are instantly preceded by the conception (X 20 ), on the basis of which the Virgin did not conceive the whole man by the Holy Spirit ${ }^{64}$. This is supported by the claim that "they wish to attribute the soul to something extrinsic (volunt extrinsecus animam) and not to the Holy Spirit, as they also do the body" ${ }^{\prime \prime}$. This is contradictory to the belief of the Virginal conception of Jesus by the Holy Spirit - in the sense that Jesus' conception is deprived of supernatural intervention and is rather quite natural ${ }^{66}$. Hilary concludes that according to such unacceptable interpretation, Lord Jesus would then receive Adam's body and soul from Mary, body and soul that bore the effects of the Original $\mathrm{Sin}^{67}$, which would mean that Jesus himself bore its effects and that he was not impeccable or sinless. As Simonetti noted, this doctrine could implicate traducionism, although the emphasis could be put on a mere natural provenance of Jesus' soul and body with all its consequences $^{68}$. Hilary puts particular emphasis on the fact that, according to this doctrine, the soul of the man who is born of the Virgin comes from an origin other than the Spirit ${ }^{69}$. Perhaps, Hilary's understanding of Photinus' doctrine

${ }^{63}$ Cf. ibidem X 22, SCh 462, 200-206.

${ }^{64}$ Cf. ibidem X 20, SCh 462, 200: "Quamquam multi confirmandae hereseos suae arte ita aures inperitorum soleant inludere, ut quia et corpus et anima Adae in peccato fuit, carnem quoque Adae adque animam Dominus ex virgine acceperit, neque hominem totum ex Spiritu sancto virgo conceperit".

${ }^{65}$ Ibidem X 22, SCh 462, 204: "Volunt extrinsecus animam, non ex Spirito sancto, ut et corpus ex eo conceptus est, deputare", transl. McKenna, p. 413. Cf. also ibidem X 21, SCh 462, 202: "Cum hominem illum humanae potius originis causa, quam spiritalis conceptionis sacramentum animaverit".

${ }^{66}$ As already stated by Simonetti (Studi sull'arianesimo, p. 158), who furtherly comments: "Ma qui Ilario vuol dire soltanto che egli non ravvisava l'azione dello Spirito Santo nella nascita di Cristo da Maria cosi come la profilava Fotino, data l'insistenza di questo sull'elemento naturale in questa nascita, a discapito - aparente o reale - del soprannaturale", ibidem, p. 158, n. 117. According to Epiphanus' testimony, denying of the Jesus' conception by the power of the Holy Spirit is not part of Photinus' doctrine. In A. Grillmeier (Gesù il Cristo nella fede della Chiesa, I/1, Brescia 1982, 246, n. 151), we can find that Hilary counts among those Church Fathers who considered Photinus as being one of the Ebionites who held that Christ was born virginally of Mary.

${ }^{67}$ Cf. Hilarius Pictaviensis, De Trinitate X 20, SCh 462, 200: "Ut quia et corpus et anima Adae in peccato fuit, carnem quoque Adae adque animam Dominus ex virgine acceperit, neque hominem totum ex Spiritu sancto virgo conceperit".

${ }^{68}$ Cf. Simonetti, Studi sull'arianesimo, p. 158. L.A. Speller (New Light on the Photinians, p. 103, n. 29) based on Ambrosiaster (Commentarius in Titum III 9; Quaestiones Veteris et Novi Testamenti XXIII) claims that neither the Photinians nor Arians would ever say that the soul can be passed from parent to a descendent.

${ }^{69}$ Cf. Hilarius Pictaviensis, De Trinitate X 22, SCh 462, 202-204: "Per id vero, quod tristis est anima sua usque ad mortem et quod potestatem habet animae suae ponendae et resumendae, volunt extrinsecus animam, non ex Spiritu sancto, ut et corpus ex eo conceptum est, deputare". In a previous chapter (ibidem X 21) Hilary points out that, according to the mentioned doctrine, Christ the Man assumed His soul through merely human conception. Cf. ibidem X 21, SCh 462, 202: "Ut cum hominem illum humanae potius originis causa, quam spiritalis conceptionis sacramentum animave- 
of the Incarnation is clearer when contrasted to Hilary's understanding of the Incarnation, according to which the Son of God Himself and by his own act (through Himself) assumes the body of the Virgin (per se sibi ex Virgine) and he prepares (i.e. creates) for Himself a soul by his own power (from himself, ex se $)^{70}$. It should be noted that here assumption of the body implies natural contribution of the Virgin ${ }^{71}$ whereas in the assumption i.e. creation of the soul this contribution is excluded, which is, as claimed by Hilary, relevant to all people $^{72}$. A prerequisite for the true Incarnation of the Word is certainly that this Word is not an impersonal God's power but the subsistent Son of God ${ }^{73}$.

As to a formal aspect of Photinus' understanding of the apparent Incarnation, we saw that, according to Hilary, the Word of God, taken as a part of the Father's powers, extends himself by a sort of unbroken continuity thus indwelling (habitaverit) a man who began to exist in Mary ${ }^{74}$. This doctrine provides the answer to the question what was "assumed" (took on) of the humanity by the Word of God for the purpose of Incarnation, in Hilary's interpretation of Photinus' view: it is the man it assumed, not just single specific human nature consisting of soul and body, but the entire and already conceived man, a human person, whose existence begins in Mary, and in whom the impersonal Word of God indwells.

rit". This fact would imply the subjection to Original sin and, consequently, to ignorance, passions etc.; cf. infra, n. 80 as well as n. 67. It is worth to point out that Grillmeier (Gesù il Cristo nella fede della Chiesa, I/1, p. 246, n. 151) referring to our theme, offers an interesting data (the author A. Orbe, Cristología gnóstica. Introduccion a la soteriologia de los sighs II y III, BAC 384/385, Madrid 1976, 351-379) that various Gnostics can be identified at "the edges of Ebionism". Under the wing of Gnosticism of the Valentinian School, there were those who argued that Jesus was born of Mary excluding the true filiation, those who thought Jesus' virginal birth by Mary and others who thought that He was born of Joseph and Mary (the school of the Ebionites). Beside other views, the doctrine of the Valentinian School would include attitudes referring to Jesus who, since born of people, was subjected to Original sin, which implies ignorance, passions, etc.

${ }^{70}$ Cf. Hilarius Pictaviensis, De Trinitate X 15, SCh 462, 194; X 22, SCh 462, 202.

${ }^{71}$ As the mother, the Virgin contributes to conception (ibidem X 17, SCh 462, 198), growth (ibidem X 16, SCh 462, 196), development (ibidem X 15, SCh 462, 194) and birth (ibidem X 16, 6, SCh 462, 196; X 17, 5, SCh 462, 198) of the Lord's body by that which it is immanent to the female nature (ibidem X 16, SCh 462, 196; ibidem X 17, SCh 462, 198).

${ }^{72}$ Cf. ibidem X 22, SCh 462, 202: "Si enim conceptum carnis nisi ex Deo virgo non habuit, longe magis necesse est anima corporis, nisi ex Deo, aliunde non fuerit".

${ }^{73}$ Cf. ibidem X, 15, SCh 462, 194: "Nam quomodo Filius Dei hominis filius erit natus, vel manens in Dei forma formam servi acceperit, si non potente Dei verbo ex se et carnem intra virginem adsumere et carni animam tribuere homo Iesus Christus ad redemptionem animae et corporis nostri perfectus est natus, et corpus quidem ita asumpserit, ut id ex virgine conceptum formam eum esse serui effecerit?"

${ }^{74}$ Cf. ibidem X 50, SCh 462, 252-254: "Deus verbum tamquam pars aliqua virtutum Dei quodam se tractu continuationis extendens, hominem illus qui a Maria esse coepit habitaverit". Cf. also ibidem X 51, SCh 462, 254. 
3. The effects of the "Incarnation". If we reflect on the effects of the apparent Incarnation understood by Photinus, Hilary clearly expresses that, contrary to his own conception of the mutual and perfect in-dwelling of the two natures, according to Photinus it results in two subjects:

"There is a mere being as seen from the outside, the man animated and moved by the life of the soul in whom there dwelt the Word of God, like a certain power, as it were, of an extended voice" ${ }^{775}$.

On the one hand it is, thus, an ordinary man conceived and born by Mary ${ }^{76}$. Referring to Photinus' doctrine, Hilary has emphasized this reality in different ways many times ${ }^{77}$. Jesus Christ is a man ${ }^{78}$, "man with merely an ordinary soul and body (animae solum communis et corporis homo)", like ours, including, as we have seen, their origin and all its consequences ${ }^{79}$. That man is moved and animated by his very soul ${ }^{80}$ - obviously his unique vital and, it seems, operative principle. Based on Hilary's interpretation of Photinus' doctrine the soul as well as the body could have been affected by the Original sin. Understanding according to which the Son is a mere man, born of Mary, was condemned

${ }^{75}$ Ibidem X 51, SCh 462, 254: “Aut rursum per exteriorem rudamque naturam hominem illum sola vita animae noventis animatum, in quo verbum Dei, id est quaedam quasi potestas extensae vocis habitauerit", transl. McKenna, p. 438 (we have slightly altered the beginning of the English citation which actually beginns "By means of an external and separated nature, that man was animated").

${ }^{76}$ The understanding of Jesus Christ as a mere man is one of the most characteristic features of Photinus' doctrine. Such an understanding of Fotinus' doctrine Simonetti, (Studi sull'arianesimo, p. 139, and n. 27; ibidem, p. 151 and n. 80-85) names "a cliché" which he identified in the works of the following authors: the Sirmian Anathema no. 9; Rufinus, Expositio symboli 37; Augustinus, Sermo 71; Vigilius Tapsensis, Contra Arianos dialogus I 10. The same understanding of Photinus' doctrine according to Speller (New Light on the Photinians, p. 102-103 and n. 24; ibidem, p. 113) may be found also in Gregorius Elvirensis, De Trinitate 41; Filastrius Brixiensis, Diversarum hereseon liber 64-65 who considers Photinus Judaizer because of his denying the personal existence of the Word and because of his teaching that Christ was a mere man and not truly God, and therefore associates him with Paul Samosata; Ambrosiaster, Quaestiones Veteris et Novi Testamenti XCI 12-13; Socrates, HE II 18. Epiphanius Salamiensis (Panarion, transl. Williams, p. 151) does not attribute this conception to Photinus but just associates him with Paul Samosata who represented this doctrine. Hanson (The Search for the Christian Doctrine of God, p. 237) defines Photinus' understanding of the Son as "whole human being who was born of Mary".

${ }^{77}$ Cf. Hilarius Pictaviensis, De Trinitate II 4, SCh 443, 280; VII 7, SCh 448, 290 (Smulders refers to this chapter and comes to the same conclusion, cf. Smulders, La doctrine trinitaire de S.Hilaire de Poitiers, p. 96); Hilarius Pictaviensis, De Trinitate X 50, SCh 462, 254; X 51, SCh 462, 254; X 61, SCh 462, 270.

${ }^{78}$ Cf. ibidem X 50, SCh 462, 252: "Aut omnino nec fuerit Christus homo natus, quia in eo Deus verbum modo Spiritus profetalis habitaverit".

${ }^{79} \mathrm{Cf}$. ibidem X 51, SCh 462, 254: "Aut rursum per exteriorem rudamque naturam hominem illum sola vita animae noventis animatum, in quo verbum Dei, id est quaedam quasi potestas extensae vocis habitaverit", transl. McKenna, p. 438.

${ }^{80}$ Cf. ibidem X 50, SCh 462, 254: "Animae tamen suae motu naturaque viventem", that is, "Sola vita animae moventis animatum"; X 51, SCh 462, 254. 
by the Sirmian Anathema no. $9^{81}$. In De synodis Hilary comments that it is unacceptable to declare the Son of God is born of Mary without declaring that he is both God and Man ${ }^{82}$. Moreover, he comments the Sirmian Anathema no. 10, which condemns one who would, saying that Mary gave birth to both God and Man, understand by that the Unborn God being born of Mary. For the Father, points out Hilary, is "distinguished from the Son, but not under the head of nature or by diversity of substance, but only by such pre-eminence as His birthless nature gives" $" 83$.

Impersonal, the non-subsistent Word of the Father dwelling in the man - whose nature has been discussed in the first part of the article - presents, according to Photinus, the second subject issuing from the union of the divine and the human ${ }^{84}$. Based on De Trinitate and to Photinus' understanding, the Word, from the ontological point of view, can not be attributed any novum after the Incarnation.

As already shown, the union of the man born of Mary and the non-subsistent Word of God that extends in Him, is reduced to the in/dwelling ( $\mathrm{in} / \mathrm{habi}$ tatio) of the Word in that man in the manner the Spirit (of prophecy) dwells in the prophets ${ }^{85}$. As Photinus understans it, according to Hilary, the effect of the dwelling of the Word (understood as a part of God's powers) in the man (or perhaps the dwelling itself) can be taken as prophetal inspiration, animation ${ }^{86}$, which consists of mere external (extrinsecus) strengthening of the man for the power (ad virtutem) of his activities, or of equipping (instructing) of the man in the powers (virtutibus) of the divine activity; nevertheless, man's vital and, as it seems, operative principle would be his soul ${ }^{87}$. "The union" of the

${ }^{81}$ Cf. Concilium Sirmiense (351) Anathematismi 9, SCL 1, 203: "Si quis hominem solum

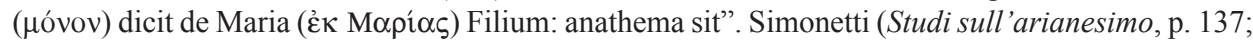
cf. ibidem, p. 154, n. 99) holds that it is certainly directed against Photinus; Kelly (Early Christian Creeds, p. 281) relates it to the typical attitudes of Marcellus and Photinus.

${ }^{82}$ Cf. Hilarius Pictaviensis, Liber de Synodis seu de Fide Orientalium 46, PL 10, 515.

${ }^{83}$ Ibidem 47, PL 10, 515: "Patre a Filio non naturae nomine, quia nec diversitate substantie, sed sola innascibilitatis auctoritate discreto". Concilium Sirmiense (351) Anathematismi 10, SCL 1, 203: "Si quis Deum et hominem de Maria natum dicens, Deum innascibilem ( intellegit: anathema sit". Simonetti (Studi sull'arianesimo, p. 157, n. 112a) holds that this Anathema can not be considered directed against Photinus with certainty.

${ }^{84}$ Cf. Hilarius Pictaviensis, De Trinitate X 51, SCh 462, 254, infra, n. 75.

${ }^{85}$ Cf. ibidem X 50, SCh 462, 252: "Aut omnino nec fuerit Christus homo natus, quia in eo Dei verbum modo Spiritus profetalis habitaverit"; X 21, SCh 462, 202: "Ut in profetis Spiritus profetiae, ita in Iesu verbum dei fuerit"; X 22, SCh 462, 254: "Alium nescio quem tamquam profetam verbo Dei animatum predicabimus". This and previous conclusion already in Simonetti, Studi sull'arianesimo, p. 143, based on Hilarius Pictaviensis, De Trinitate X 21 and 51.

${ }^{86}$ Cf. Hilarius Pictaviensis, De Trinitate X 22, SCh 462, 254: "Alium nescio quem tamquam profetam verbo Dei animatum predicabimus".

${ }^{87}$ Cf. ibidem X 50, SCh 462, 252-254: "Deus verbum tamquam pars aliqua virtutum Dei quodam se tractu continuationis extendens, hominem illum qui a Maria esse coepit habitaverit et virtutibus divinae operationis instruxerit, animae tamen suae motu naturaque viventem"; X 51, SCh 
Word and the man is only a temporary and accidental, which is confirmed by the fact that the extension of the Word is withdrawn on the $\operatorname{cross}^{88}$. Simonetti claims that the relationship of Logos and Christ is clearly outlined by Hilary as adoptionist ${ }^{89}$.

What was Photinus' understanding of the Divine Sonship according to Hilary's interpretation? We saw that in De synodis Hilary referred to the heretical view (associated by him with the Sirmian Anathema no. 7), according to which the extention, effected by expansion of the Divine substance and assuming the Man, is called the Son ${ }^{90}$.

This issue is not thoroughly analysed in De Trinitate, however, according to it, it seems that Photinus' understanding of the Divine Sonship implies a certain union of the Word of God and man who was born of Mary, the union understood as merely accidental habitatio of the Word of God in that Man.

462, 254: "Hominem illum sola vita animae moventis animatum in quo verbum Dei [...] habitaverit $[\ldots]$ Christus Iesus, animae solum communis et corporis homo, hoc habeat sui quo esse homo coepit exordium, quem extrinsecus protensi sermonis potestas ad virtutem operationum confirmaverit". This operation of the Word (word) in the man Christ will be characterised by Smulders (La doctrine trinitaire de S. Hilaire de Poitiers, p. 96) as accidental (extrinsecus).

${ }^{88}$ Cf. Hilarius Pictaviensis, De Trinitate X 51, SCh 462, 254: "Qui nunc a Dei verbo contracta rursum protensione desertus clamet: «Deus Deus meus, quare me dereliquisti?»". Referring to the available sources Simonetti (Studi sull'arianesimo, p. 151) defines the relationship between the man Jesus and the Word as the following: "in forma quanto mail labile ed esteriore, alla maniera degli adozionisti", that is, the union would be just moral, "una pottente ispirazione soprannaturale da cui il Cristo avrebbe tratto la forza di operare quelle prodigiose azione che gli avrebbero meritato l'adozione come Figlio di Dio e l'assunzione alla destra del Padre, dopo la resurrezione".

${ }^{89}$ Cf. Simonetti, Studi sull'arianesimo, p. 155. Simonetti (ibidem, p. 152-155) referring to the sources, distinguishes two possible Photinus' Christologies: Trennungschristologie, which would be specific of a strict distinction of Christ as a human subject imbued with the divine spirit, and Christology that preserves the wholeness of Christ's humanity associating it more intimately with the divine factor, the subject of the Incarnation in a true sense. The latter would refer to the one outlined by Epiphanius Salamiensis, Panarion 71, 3, according to which the Logos was incarnated by trasnforming into the body, which is confirmed by the Sirmian Anathemas no. 9 and indirectly no. 10. Hilary would be a representative of the first, the Adoptionistic group. Simonetti supports this by the fact that due to Photinus' insistence on the wholeness of Christ's humanity Hilary considered him a follower of Adoptionism or maybe Hilary referred to less reliable sources or did not deal with the issue ex professo. M. Simonetti holds that Hilary's attitude can be interpreted in a way that, being focused on Photinus' insistence on the wholeness of Christ's humanity, he did not find any difficulty in interpreting the relationship between the Logos and Christ in a wider and more extrinsic sense, than it was originally done by Photinus, and that closer relationship in this regard seemed inconceivable. If indeed Epiphanius' testimony, along with the Sirmian Anathemas, are more credible sources, the interpretation of Photinus' doctrine as an adoptionistic would refer to its later stage, as stated by Simonetti. However, Hanson (The Search for the Christian Doctrine of God, p. 237) holds that the entire ancient world attributed to Photinus the reduction of Christ to a mere man whom God would adopt, which corresponds to the assumption that the union of the Word-Logos and the man would just be a moral one and the union of the inspiration.

${ }^{90}$ Cf. Hilarius Pictaviensis, Liber de Synodis seu de Fide Orientalium 45, PL 10, 514. 
According to Hilary in De Trinitate, Photinus claims that the Son of God, Christ, (even) the Word, begins to exist or subsist only through the Incarnation $^{91}$, i.e. the birth of Mary ${ }^{92}$. He has no pre-existence ${ }^{93}$, because before the birth of Mary, the Word was not by nature only-begotten Son of God endowed with existence, but was a mere utterance of a voice ${ }^{94}$. He was not co-Creator of the world ${ }^{95}$. Therefore, Photinus excludes his eternal generation ${ }^{96}$ including him in the time ${ }^{97}$. The Sirmian Anathema no. $27^{98}$, and possibly no. $3^{99}$ are

${ }^{91}$ The first condemnation of Photinus by the Council, so called Ekthesis Makrostichos in 344 condemns him because of the claim that: "He was not Christ or Son of God or mediator or image of God before ages; but that He first became Christ and Son of God, when He took our flesh from the Virgin" (Williams, Monarchianism and Photinus of Sirmium, p. 196). Williams points out (ibidem, p. 187) that Photinus was mostly censured for his viewpoint denying the existence of the Son before His birth in Betlehem.

${ }^{92}$ Cf. Hilarius Pictaviensis, De Trinitate II 23, SCh 443, 312: "Initium Filio Dei ex Maria concendens". Cf. also ibidem X 50, SCh 462, 252: "Ne Iesus Christus, antequam ex Maria natus est, Christus sit: dum non qui erat natus est, sed ad id tum primum quod natus est coeperit"; X 51, SCh 462, 254: "Aut omnino Christus ante partum Mariae non fuerit: quia Christus Iesus, animae solum communis et corporis homo, hoc habeat sui quo esse homo coepit exordium"; II 4, SCh 443, 280: "Ut Hebion omne initum ex Maria concedens, non ex Deo hominem, sed ex homine Deum proferat"; II 23, SCh 443, 312: "Verbum a diebus carnis intellegens". The same is for the subsisting Wisdom of God, cf. ibidem XII 36.

${ }^{93}$ Cf. ibidem VII 3, SCh 448, 280-282; VII 7, SCh 448, 290: "Ei, quia ante saecula Filium nesciat". This Photinus' claim is highlighted by Hanson (The Search for the Christian Doctrine of God, p. 237) and Smulders (La doctrine trinitaire de S. Hilaire de Poitiers, p. 97) based on Hilary's complete works.

${ }^{94}$ Cf. Hilarius Pictaviensis, De Trinitate II 4, SCh 443, 280: "Ut Hebion omne initium ex Maria concedens, non ex Deo hominem, sed ex homine Deum proferat: neque subsistens antea quod «in principio apud Deum erat deus verbum» virgo susceperit, sed carnem genueit per verbum: quia in verbo antea, non existentis unigeniti Dei naturam dicat, sed sonum vocis elatum".

${ }^{95}$ Cf. ibidem VII 7, SCh 448, 290: "Ecclesiae fides [...] tenet [...] adversus Fotinum saeculi creatorem".

${ }^{96} \mathrm{Cf}$. ibidem: "In usurpato sibi homine nativitatem Dei ante saecula ignorat".

${ }^{97} \mathrm{Cf}$. ibidem II 16, SCh 443, 304. Hilary condemns this viewpoint referring to Jn 1:2.

${ }^{98}$ Cf. Concilium Sirmiense (351) Anathematismi 27, SCL 1, 205: "Si quis Christum Deum Filium Dei ante saecula subsistentem ( $\pi \rho \circ \alpha \iota \omega ́ v ı v ~ \hat{v} \tau \tau \alpha)$ et ministrantem ( omnium perfectionem (universorum opificium) non dicat, sed ex quo de Maria natus est, ex eo et

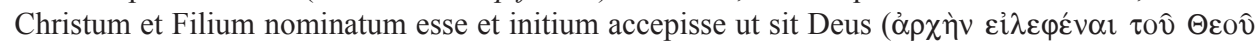
Eîvol) dicat: anathema sit". Simonetti (Studi sull'arianesimo, p. 137) and Kelly (Early Christian Creeds, p. 281) claim that the Anathema is directed against both Marcellus and Photinus; According to Williams (Monarchianism and Photinus of Sirmium, p. 201) the Anathema summarizes Photinus' viewpoints. The Anathema is commented by Hilary in Liber de Synodis seu de Fide Orientalium 61, PL 10, 522. He points out that the corner-stone of faith, according to the evangelical and apostolic doctrine, is the fact that the Lord Jesus Christ, God and the Son of God, can not be separated from the Father either at the level of honor, power, nature or interval of time.

${ }^{99}$ Cf. Concilium Sirmiense (351) Anathematismi 3, SCL 1, 202: "Et si quis, unum dicens Deum, Christum autem Deum ante saecula Filium Dei obsecutum Patri in creatione omnium non confitetur

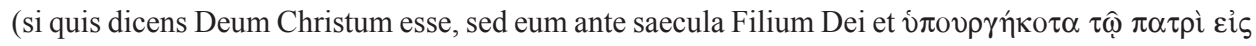


directed against these viewpoints. Epiphanius also censures Photinus for the denial of Christ's pre-existence and identifiying the beginning of His existence with the birth of Mary ${ }^{100}$.

Based on Hilary, Photinus' position is clearly adoptionist: Photinus "assumes, unlawfully, a man into the Son" and into the God ${ }^{101}$. Taking all into consideration, it seems reasonable to think that - though relying on scarce information in Hilary's De Trinitate - this "Divine Sonship" or filiation and "deification" of man born of Mary, according to Photinus, are due to the fact that the non-subsisting Word of God - a part of God's powers - dwells in him, inspiring or animating him by strengthening and empowering him for divine activity ${ }^{102}$.

On the basis of all the mentioned elements of Photinus' doctrine, Hilary concludes that such understanding of the union of the human and divine does not result in true Incarnation of the divine Person: "the subsisting Word of God who remains in the form of God was not born as Christ the man"103. To Hilary, the man born of Mary cannot really be Christ because the word in him resides only in an indwelling way as the Spirit has dwelt in the prophets. Hilary's interpretation of Photinus' understanding of Jesus Christ is that the Son of God can neither be the Word that was made flesh, nor one and the same both God and Man ${ }^{104}$. Hilary's criticism of such position on the apparent Incarnation offers its negative definition: "He was born, however, not that He might be two

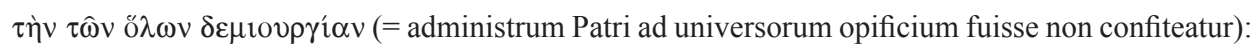
anathema sit".

${ }^{100}$ Cf. Epiphanius Salamiensis, Panarion 71, 1; 71, $2-5$.

${ }^{101}$ Cf. Hilarius Pictaviensis, De Trinitate VII 7, SCh 448, 290: "Homo ab eo usurpatur in filium"; II 4, SCh 443, 280: "Ut Hebion omne initium ex Maria concendens, non ex Deo hominem, sed ex homine Deum proferat". Vigilius Tapsensis (Contra Arianos dialogus I 4; I 11) wrote that Photinus taught that Christ would have been God because of the adoption by the Father because of the merita bonae actionis, cf. Simonetti, Studi sull'arianesimo, p. 139; Hanson, The Search for the Christian Doctrine of God, p. 238.

${ }^{102}$ Simonetti, referring to the available sources (Studi sull'arianesimo, p. 150, n. 79.) concluded that Photinus sharply distinguish Logos which exists ab aeterno and Christ born of Mary. According to Simonetti, Photinus identified the Son of God with Christ, not with Logos, the Word of God, claiming that the Son of God was born only of Mary, but this does not necessarily mean that the one to whom Mary gave birth was a mere man. Cf. also Simonetti's opinion on the Sonship expounded infra, n. 89. Smulders (La doctrine trinitaire de S. Hilaire de Poitiers, p. 96) referring to Hilarius Pictaviensis (De Trinitate II 4, SCh 443, 280) concluded that the man born of Mary is named the Son and the Word of God because of His miraculous birth of the Virgin by divine intervention.

${ }^{103}$ Hilarius Pictaviensis, De Trinitate X 21, SCh 462, 202: "Ne subsistens verbum Deus et manens in forma Dei Christus homo natus", transl. McKenna, p. 412. Cf. ibidem X 50, SCh 462, 252: "Aut omnino nec fuerit Christus homo natus, quia in eo Dei verbum modo Spiritus profetalis habitaverit".

${ }^{104}$ Cf. ibidem X 22, SCh 462, 202: "Et cum ipse ille filius hominis ipse sit qui et Filius Dei, quia totus hominis filius totus Dei filius sit, quam ridicule praeter Dei Filium qui «verbum caro factum est», alium nescio quem tamquam profetam verbo Dei animatum praedicabimus, cum Dominus Iesus Christus et hominis filius et Dei filius sit!". 
separate beings, but that the God before the man, since He assumed the human nature, might be recognised as both man and God" 105 . Hilary inferred that according to Photinus' Christology, the man born of Mary, and the subject of the "Incarnation" i.e. the Word dwelling in him are clearly different and make two subjects. It is therefore clear why Hilary reproaches to Photinians dividing "Christ into three parts - the Word, the soul and the body" 106 . As we have seen, for Hilary, Jesus Christ or Son of God as Photinus understands him is just someone like a prophet (a man) inspired, that is empowered by a Word of God - a part of God's powers - dwelling in him, for divine activities ${ }^{107}$. Moreover, Hilary among the many Photinus' opponents ${ }^{108}$ acused him of reducing the Son of God to a mere man ${ }^{109}$, a mere Son of Mary ${ }^{110}$, of not recognizing the Son of God in a man ${ }^{111}$ and reducing "the whole Christ, God the Word, in solum communis generis hominem" 112 , to a creature (creatura $)^{113}$. In that way, Hilary polemically assimilates Photinus' thought to that of Arians and Sabellians.

\section{Photinus and the question of Christ's soul according to the Book} Ten of De Trinitate by Hilary of Poitiers. In the end let us refer to the conclusions that are stated in the scholarship according to which Photinus insisted on the wholeness of Christ's humanity, or more precisely, on the fact that Jesus Christ possessed a human soul. These conclusions are based exclusively on Hilary's work De Trinitate ${ }^{114}$. Hilary is, all things considered, the only author that

${ }^{105}$ Ibidem X 22, SCh 462, 204: "Natus autem est, non ut esset alius adque alius, sed ut ante hominem Deus, suscipiens hominem, homo Deus posset intellegi", transl. McKenna, p. 413-414 (we have slightly altered English citation: from "first one and then another" into "two separate beings").

${ }^{106}$ Ibidem X 61, SCh 462, 270: "Vos nunc vel tripartientes Christum in verbum et animam et corpus, vel totum Christum Deum verbum in solum communis generis hominem contrahentes", transl. McKenna, p. 446. Simonetti (Studi sull'arianesimo, p. 143) pointed that these words refers to "i Fotiniani". We will offer another possible interpretation.

${ }^{107}$ Hilarius Pictaviensis, De Trinitate X 22, SCh 462, 202: "quam ridicule praeter Dei Filium qui verbum caro factum est, alium nescio quem tamquam profetam verbo Dei animatum praedicabimus".

${ }^{108}$ Cf. Speller, New Light on the Photinians, p. 103.

${ }^{109}$ Cf. Hilarius Pictaviensis, De Trinitate X 50, SCh 462, 254; X 51, SCh 462, 254.

${ }^{110} \mathrm{Cf}$. ibidem VII 7, SCh 448, 290. Hilary testifies that this standpoint of his Photinus supported by the Gospels.

${ }^{111}$ Cf. ibidem, and also I 26, SCh 443, 250.

${ }^{112}$ Ibidem X 61, SCh 462, 270, transl. McKenna, p. 446. Cf. also ibidem X 51, SCh 462, 254 : "animae solum communis et corporis homo"; X 50, SCh 462, 252-254.

${ }^{113}$ Cf. ibidem VIII 40, SCh 448, 442: "Heretici serpentes, siue Sabelli siue Fotine siue qui nunc creaturam esse unigenitum Deum praedicans!"; XII 54, SCh 462, 464: "Tua enim res est et unigenitus tuus est, non portio, non protensio, non secundum efficientiarum opinionem nomen aliquod inane, sed Filius".

${ }^{114}$ Cf. Simonetti (Studi sull'arianesimo, p. 143) based on Hilarius Pictaviensis, De Trinitate X 50: "I Fotiniani [...] insistevano particolarmente nell'atribuire a Cristo un'anima umana". Also based on ibidem X 20: "Dal passo di Ilario ricaviamo che l'insistenza di Fotino sull'umanità completa di Cristo" (cf. also infra, n. 120). Here are the reasons because of which, according to Si- 
witnessed such an opinion of Photinus ${ }^{115}$. Moreover, based on this text of Hilary, soteriological motives are attributed to such insisting attitude of Photinus ${ }^{116}$.

The work of Richard P.C. Hanson gave us also some valuable insights into the Arian understanding of the pro-Nicene Christology. He discusses about the Arian theology of the Incarnation ${ }^{117}$, according to which, in short, the Word

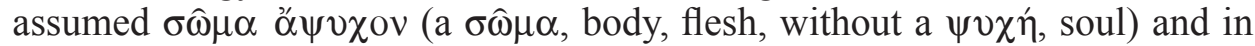
Jesus Christ took the place of the human soul (this understanding is witnessed also by Hilary) ${ }^{118}$, which makes the constant and focal point of the Arian doctrine ${ }^{119}$. R.P.C. Hanson's work also enabled a better understanding of Hilary's interpretation of the doctrines of his opponents. In the works of Arian authors, such as Asterius, Eudoxius, Pseudo-Ignatius and Opus imperfectum in Matthaeum, R.P.C. Hanson saw the authors' condemning of statements according

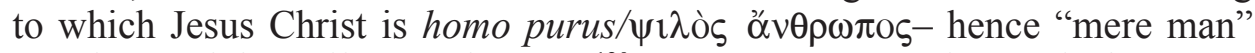
- and as such he suffers on the cross ${ }^{120}$. R.P.C. Hanson understands the mean-

monetti, Epiphanius Salamiensis does not emphasize, contrary to Hilary, this fact. Simonetti (Studi sull'arianesimo, p. 144-145 and 157-158) claims that Hilary emphasized this fact because he perceived Christ's human nature as "from heaven", which cannot be completely identified with common human body, yet especially contrary to Photinus, who perceived that the soul is coming from Mary, Hilary thought that God directly created Christ's soul, thus trying to reject his opinions. Cf. also Hanson (The Search for the Christian Doctrine of God, p. 236): "He certainly taught that the human body of Jesus had a human mind or soul, insisting on its wholeness"; Hanson is referring on the text of Hilarius Pictaviensis, De Trinitate X 20 quoted here, in n. 64, 67, 116, but instead of "Adam" in Hanson's text in both places is put "Eva"! Hanson claims that Photinus could have attributed to the prejudice against attribution of human soul to Jesus Christ or however, not seeing its necessity (Hanson, The Search for the Christian Doctrine of God, p. 238).

${ }^{115}$ Cf. Simonetti, Studi sull'arianesimo, p. 144.

${ }^{116}$ Cf. ibidem, p. 158, based on Hilarius Pictaviensis, De Trinitate X 20, SCh 462, 200: "Ut quia et corpus et anima Adae in peccato fuit, carnem quoque Adae atque animam Dominus ex Vergine acceperit". Simonetti writes: "Dal passo di Ilario ricaviamo che l'insistenza di Fotino sull'umanità completa di Cristo derivava non dalla configurazione adozionista del rapporto Logos-Cristo, bensi dal preoccupazioni di carattere soteriologico che l'eretico, ferma restando la sua errata concezione del Logos, condivideva con la più autentica tradizione ortodossa". On the basis of the whole of the Book Ten of De Trinitate, we perceived this paragraph not in the sense that the Lord took Adam's body and soul from the Virgin so he could redeem them and heal them as they are both burdened with Original Sin, but in the sense that Hilary testifies of a heretical conception (foreign to him) according to which the Lord - assuming (taking on) both body and soul from the Virgin which were Adam's - bore the consequences of the Original Sin. In this sense the text is also interpreted by the editors of notes in the critical edition of De Trinitate (cf. SCh 462, 200, n. 2). It does not seem plausible that Hilary would be interested at all in Photinus' soteriology bearing in mind the fact that he did not touch upon that of Arians - and with them he primarily debates - to the best of our knowledge.

${ }^{117}$ R.P.C. Hanson, The Arian Doctrine of the Incarnation, in: Arianism: Historical and Theological Reassessments, ed. R.C. Gregg, Cambridge (MA) 1985, 181-211.

${ }^{118}$ Cf. Hilarius Pictaviensis, De Trinitate X 50, SCh 462, 252; X 51, SCh 462, 254.

${ }^{119}$ Cf. Hanson, The Arian Doctrine of the Incarnation, p. 192.

${ }^{120}$ The example of Asterius, who does not mention directly the absence of the soul (cf. ibidem, p. 190); Pseudo-Ignatius (cf. ibidem, p. 191). 
ing of these expressions as "only (human) soul and body" 21 . He also states that for Arian authors they do not necessarily signify "an Ebionite picture, of the one who was human and not Divine", but "the pro-Nicene doctrine of the incarnate Word possessing two natures or elements, one of which was a complete man with a human mind"122. In some of Arian works which R.P.C. Hanson observed, for instance Pseudo-Ignatius' ${ }^{123}$, the doctrine of homo purus is attributed to Ebionites, while others, for example Mai/Gryson fragment (XV Mai, V Gryson) attribute it to Photinus and his predecessors (the doctrine of homo purus condemned by May/Gryson fragment R.P.C. Hanson identifies as Photinus'). R.P.C. Hanson claims that it is possible that Pseudo-Ignatius under the name of Ebionites actually refers to pro-Nicenes, "who insist that Christ's human nature was complete with a human soul, in order to shield the Divine Word from human experience" 124 , and that May/Grison fragment actually refers to Marcellus and maybe pro-Nicenes as well ${ }^{125}$. Aloys Grillmeier has noted that Pseudo-Ignatius, when the Incarnation is in question, doesn't see anything but two options - first, the true union of Logos and $\sigma \alpha \alpha^{\prime} \xi$ as in Jn 1:14 (therefore Logos and the body without human soul), which he advocates, and the second option is "«mere man» in whom God dwells: Verbum in homine"126.

After these findings shed some light on the whole situation, we have reviewed the Book Ten of Hilary's De Trinitate. Along the pro-Nicene doctrine of the Incarnation, he also points out the doctrines of his opponents, with which

${ }^{121}$ The example of Eudoxius (cf. ibidem, p. 190); also the example of Opus imperfectum in Matthaeum, (cf. ibidem, p. 191).

${ }^{122}$ Ibidem, p. 192. Hanson sometimes uses the term "mind", sometimes "soul", and sometimes even both (cf. for example ibidem, p. 188) and points out that Arianism was never dealing with the question of mind (vov̂s) and spirit ( $\pi v \varepsilon \hat{v} \mu \alpha)$ (cf. ibidem, p. 203).

${ }^{123}$ Grillmeier (Gesù il Cristo nella fede della Chiesa, I/1, p. 580) gives the same example of Pseudo-Ignatius holding him as semi-Arian, not as the Arian in the strict sense; he emphasizes that his letters mention doctrine on Christ, "mere human" in the cases when is said that Christ has a human soul, and that the claim of the wholeness of human nature of Christ in the sense of his possession of soul and body in Pseudo-Ignatius' view "corresponds to denial of his divinity and is a proof of Ebionism and Adoptionism". Pseudo-Ignatius (Epistula ad Philippenses 5, 2, according to: Grillmeier, Gesù il Cristo nella fede della Chiesa, I/1, p. 580) states: "Si quis autem dicit unum deum confiteturque et Christum Iesum, hominem vero purum putans Dominum et non Deum unigenitum et sapientiam et verbum Dei, «sed ex anima et corpore» eum existimans, huiusmodi serpens est et seductor, errorem praedicans et perditionem hominum: huiusmodi pauper est sensu, sicuti vocatur et adinventor ipsius erroris Hebion". Christ who, however, consists exclusively of $\Lambda$ ó $\gamma$ and "flesh/body" ( $\sigma \alpha ́ \rho \xi)$, is called by Pseudo-Ignatius: "unigenitus Filius, Deus verbum et homo" (cf. ibidem, p. 581; Pseudo-Ignatius, Epistula ad Philadelphios, 4, 2).

${ }^{124}$ Hanson, The Arian Doctrine of Incarnation, p. 194-195. The same opinion is present on p. 196. It is worth emphasizing that Pseudo-Ignatius' work contain segments which denie the mentioned opinion, yet Hanson identifies these parts as interpolations. Cf. ibidem, p. 195-196.

${ }^{125}$ Cf. ibidem, p. 194 and 209, and n. 73.

${ }^{126}$ A. Grillmeier, Christ in Christian Tradition, I, transl. J. Bowden, Atlanta 1975², 306; PseudoIgnatius, Epistula ad Philippenses 5, 2. 
he disputes - Arianism, Sabellianism (that of Marcellus) and aforementioned doctrine of Photinus, whom he does not mention even once by name, which seems to be quite significant. The texts from the Book Ten which deal with Photinus's point of view ${ }^{127}$ which Hilary criticises and condemns, we have tried to read primarily as the Arian interpretation of the pro-Nicene, and also Hilary's understanding of Incarnate Christ possessing two complete natures, the human nature consisting of the body and the soul. We have seen that, according to R.P.C. Hanson, this pro-Nicene Christology could be understood by Arians as "Ebionite" or as the doctrine of Photinus. It seems to us that Hilary's anti-adoptionist texts from the Book Ten of De Trinitate even understood in such a manner maintain their consistency. Furthermore, we consider highly probable that Hilary constructed them exactly like that, so that they could be primarily understood as a response to the Arian understanding of pro-Nicene Christology, according to which Jesus Christ was a "mere men", in which Arians do not see Deity, because in him, in the place of the human soul, God the Word does not dwell (in best case he is accidentally indwelled by nonsubsistent God the Word). This interpretation coincides with the doctrine of Photinus, from which, in our opinion, Hilary, in the same time, distances himself and refutes it as heretical ${ }^{128}$. That is why Hilary's words in De Trinitate X 61: "You who divide Christ into three - the Word, the soul, and the body - or who reduce the whole Christ, God the Word, into a mere man of an ordinary nature" 129 , for which were until now considered to be directed to Photinus and possibly to Apollinarians ${ }^{130}$, could be, by our opinion, in fact primarily directed to Arians.

Here we have to take into account some historical-theological factors, with which we should read De Trinitate, and which were noted by Charles Beckwith. He pointed out that "it would be difficult to overstate Hilary's constant concern to distance his pro-Nicene theology from any charge of Photinian adoptionism" and stated that in Hilary's comments of the events that took place in 340s and 350s, which he recorded, as well as in the revisions of the earlier books of De Trinitate that Hilary made in the course of the year 358, he constantly read "the sensitivity of being labelled as a Photinian"131. According to Ch. Beckwith, the history of "labelling" of pro-Nicenes as Photinians

${ }^{127}$ Cf. Hilarius Pictaviensis, De Trinitate X 20; X 21-22; X 50-51; X 61.

${ }^{128} \mathrm{Ch}$. Beckwith (Hilary of Poitiers on the Trinity, p. 31) pointed out that for anti-Nicene authors of Hilary's period "if you stand for Nicaea you must embrace the monarchial theology of Marcellus of Ancyra and Photinus of Sirmium in the spirit of the heresiarch Sabelius". See, also Kelly, Early Christian Creeds, p. 283; Williams, Monarchianism and Photinus of Sirmium, p. 203.

${ }^{129}$ Hilarius Pictaviensis, De Trinitate X 61, SCh 462, 270.

${ }^{130}$ Simonetti (Studi sull'arianesimo, p. 143) as we saw (cf. n. 9) claims that they were addressed to Photinians; the editors of notes in the critical edition of De Trinitate (SCh 462, 271, n. 2,) presume that Hilary is debating with predecessors of Apollinaris and simultaneously with Photinus.

${ }^{131}$ Cf. Beckwith, Hilary of Poitiers on the Trinity, p. 31. For details on revisions, cf. ibidem, p. $72-147$. 
started after the council of Milan in the year 345 where the western bishops did not accept the subordinationist positions of the eastern bishops as formulated in Ekthesis Makrostichos, thence the easterners falsely interpreted this rejection as a support of the monarchianism of Marcellus and Photinus, latter condemned both by East and West ${ }^{132}$. Furthermore, on the council of Syrmium in the year 351 eastern bishops took advantage of the Photinus's condemnation to associate falsely his theology via Marcellus of Ancyra to Athanasius and Nicene faith, all in the purpose of the condemnation of the last two ${ }^{133}$. The same goal tried to be accomplished in the western councils in Arles (353), Milan (355) and finally, Béziers (356), which exiled Hilary ${ }^{134}$.

These insights, as it seems, shed a new light on the opinions according to which Photinus, according to Hilary, insisted on the wholeness of Jesus Christ's humanity putting emphasis on the fact that Jesus Christ possessed a human soul, furthermore, with the soteriological motivation, because the human soul was as well as the body burdened by the Original sin. Let us be reminded that these opinions are based exclusively on Hilary's texts from the Book Ten of De Trinitate, not taking into the account the possibility that Photinus's doctrine presented there could be understood as the Arian interpretation of pro-Nicene Christology, out of which in these texts Hilary is distancing himself from and is refuting it. In the Book Ten, in addition, as we saw, Photinus was not mentioned by name even once, despite the fact that, in the seventh book, Hilary identifies Ebion, with whom, until that moment, among others, he openly debated, as Photinus ${ }^{135}$.

In our opinion, according to Hilary's texts, one can claim that Photinus insisted on the wholeness of Jesus Christ's humanity, namely on his possessing of the human soul, only to that extent which he held that Jesus Christ is (a mere) man, thus his human nature is self-explicatory. This potential Photinus's insistence could be completely logical, since God's word which will dwell in him does not have personal individuality, and in the case that Jesus Christ does not have a human soul, there would not be a subject at all.

On the contrary, in the Book Ten of De Trinitate, to show that after the Incarnation Christ has a human soul is Hilary's priority. There he disputes with and refutes Photinus's adoptionism, but as in the Book Nine alike, primarily he refutes Arians according to whose understanding of the Incarnation, "God the Word exist as the soul of the body through a change in His nature that weakens Him and He ceases to be God the Word" ${ }^{\prime 36}$. By means of the mystery of Incar-

${ }^{132}$ Cf. ibidem, p. 36; in more details p. 32-36.

${ }^{133}$ Cf. ibidem, p. 41, in more details p. 36-43.

${ }^{134}$ Cf. ibidem, p. 43-48.

${ }^{135}$ On this identification cf. Beckwith (ibidem, p. 83); Hilarius Pictaviensis, De Trinitate VII 3 , SCh 448, 280; VII 7, SCh 448, 290.

${ }^{136}$ Hilarius Pictaviensis, De Trinitate X 51, 2-4, SCh 462, 254: "ut aut Deus verbum anima corporis per demutationem naturae se infirmantis extiterit et verbum Deus esse defecerit", transl. 
nation, the Arians are trying to show the inferiority of the Son, God the Word, in relation to the Father, which reaches also to unlikeness of the Son to the Father. Those things the Jesus Christ spoke as human, as well as human limitations, necessities and weaknesses - hunger, thirst, fear of passion and pain of suffering, the necessity of subjection to suffering and death, are (thanks to the

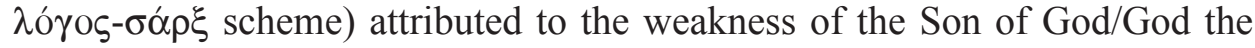
Word so the Arians could deny the unity of nature which results from eternal generation of the Son from the Father and reduce it to the unity of will. Son would have been a God only by name, not by nature, a God of different kind, or he would not have been God at all, but creature (creatura) ${ }^{137}$.

In the Book Ten, Hilary is trying to show against the Arians that in Jesus Christ one person subsists in two natures ${ }^{138}$ : the Divine ${ }^{139}$, so he could perform miracles ${ }^{140}$, forgive us our sins on the $\operatorname{cross}^{141}$, reconcile us with God and redeem us ${ }^{142}$, and resurrect ${ }^{143}$, and the human, consisting of the body ${ }^{144}$ and the soul ${ }^{145}$, whose place was not taken by God's Word/God the Word, so he in his solidarity with mankind could suffer and die ${ }^{146}$. The insisting on the Jesus Christ's human soul (on the wholeness of Chist's humanity) is beyond

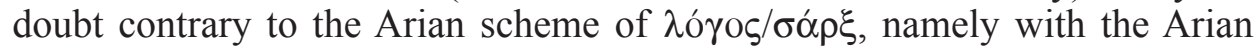
position on which points out A. Grillmeier, the principle which supposes that

McKenna, p. 438 (we have altered the end of the english citation from "he ceases to be God the Word" into "the Word ceases to be God"). Cf. ibidem X 51, 8-9, SCh 462, 254; X 50, SCh 462, 252.

${ }^{137}$ Cf. ibidem IX 2, SCh 462, 14-16; IX 5, SCh 462, 22-24; IX 70, SCh 462, 158-160; X 3, SCh 462, 176-178; X 5, SCh 462, 180; X 7-10, SCh 462, 182-188; X 27-29, SCh 462, 216-218; X 32, SCh 462, 220; X 36, SCh 462, 226; X 41, SCh 462, 236; X 45, SCh 462, 242-243; X 46, SCh 462, 244-246; X 48-49, SCh 462, 250-252; X 55, SCh 462, 262-264; X 71, SCh 462, 290-292.

${ }^{138} \mathrm{Cf}$. for example ibidem IX 14, SCh 462, 40: "Haec igitur demonstranda a me paucis fuerunt, ut utriusque naturae personam tractari in Domino Iesu Christo meminissemus"; X 21, SCh 462, 202: "Vere Dei Filius Verus hominis filius natus sit"; XI 16, SCh 462, 324: "Verbum autem Deus neque verbum esse desiit, neque caro non fuit. Nam «verbum» quod «caro factum est et habitavit in nobis», neque dum habitat non uere verbum esse qui maneat, et carnem fieri eius intellegendum sit esse qui maneat, et carnem fieri eius itellegendum sit esse qui nascitur".

${ }^{139}$ Hilary persistantly repeats, referring to Col 2:9, that in Christ dwells all the fullness of the Godhead bodily: cf. ibidem II 8, SCh 443, 290; II 11, SCh 443, 294; II 20, SCh 443, 308; III 3, SCh 443, 338; III 15, SCh 443, 362; III 17, SCh 462, 366; III 23, SCh 443, 378; VI 10, SCh 443, 188; VIII 53-56, SCh 443, 464-468; IX 1, SCh 462, 12; XI 15, SCh 462, 320.

${ }^{140} \mathrm{Cf}$. for example, ibidem VII 36, SCh 448, 356-358.

${ }^{141} \mathrm{Cf}$. ibidem X 48, SCh 462, 248.

${ }^{142}$ Cf. ibidem VII 51, SCh 448, 460.

${ }^{143} \mathrm{Cf}$. for example, ibidem IX 10, SCh 462, 32-34.

${ }^{144}$ Cf. for example ibidem X 41, SCh 462, 236; X 60, SCh 462, 272; X 19, SCh 462, 198-200.

${ }^{145}$ For example: ibidem X 19, SCh 462, 200: "Ita Iesus Christus per virtutem suam carnis adque animae homo ac Deus esset, habens in se et totum verumque quod homo est et totum verumque quod Deus est"; X 57, SCh 462, 266-268.

${ }^{146}$ Cf. ibidem V 18, SCh 448, 128: "Deus ergo idirico tibi Christus non est, quia qui erat nascitur, quia qui imdemutabilis est crescita aetate, quia inpassibilis patitur, quia vivens moritur, quia mortuus vivit, quia omnia in eo contra naturam sunt". 
"the real Incarnation can only take place if the Word that comes from the heaven really enters into a substantial conjunction with the flesh and become its life-principle" 147 . As was pointed out by A. Grillmeier, it is significant for the state of Christology before Apollinarist controversy that "those who recognize Christ's humanity to be complete, with body and soul, already appear as betrayers of the true union of the God and man"148. In these circumstances, it is a small step to identify pro-Nicene Christology with Photinus's adoptionism. Thus, for Hilary, it was of the crucial importance to show (against the Arians) that alongside Christ's assuming (appropriating) of the complete human nature to himself - body but also human soul ${ }^{149}$, Jesus Christ is one and the same, one subject, one person; namely, that the union of Son of God/God the Word and of human nature resulted in one subject, one person, which is both God and a man ${ }^{150}$. According to Hilary that person is identical with the eternally pre-existent person of Son of God, God the Word, Christ (subject of the Incarnation) $)^{151}$, who before the Incarnation was just a God, and after the

${ }^{147}$ A. Grillmeier (Christ in Christian Tradition, I, p. 247) pointed out that Arians speculate

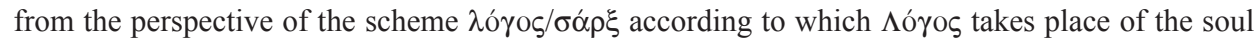
and enters in a natural union with the body. In such manner is formed a "human being", which means that the Word enters in physical conjunction with the body in such a way that from two arises a con-stitutio".

${ }^{148}$ Ibidem, p. 307.

${ }^{149}$ Cf. Hilarius Pictaviensis, De Trinitate X 56, SCh 462, 264-266: "Et tamen quaero, cui inputabur fletus ille, Deo an animae an corpori? Sed corpus per se tantum non habet lacrimas, quas ad dolorem animae maerentis profundit. Longe autem minus est, ut Deus fleverit, qui glorificandus in Lazaro est. Non convenit autem, ut anima de sepulchro Lazarum vocet, et ad animae innexae corpori praeceptum adque virtutem in mortuum suum anima iam ex eo dissoluta revocetur. Dolet, qui glorificatus est? Flet, qui vivificaturus est? Non est vivificaturi flere nec glorificandi dolere; et tamen vivificat qui et flevit et doluit"; X 57, SCh 462, 266-268.

${ }^{150}$ Cf. for example: ibidem X 52, SCh 462, 256: “Totum ei Deus verbum est, totum ei homo Christus est: retinens hoc in sacramento confessionis suae, nec Christum aliud credere quam Iesum, nec Iesum aliud praedicare quam Christum"; X 22, SCh 462, 204: "Vt vero adsumpsisse formam servi non aliud est quam hominem natum esse, ita in forma Dei esse non aliud est quam Deum esse: unum tamen eundemque non Dei defectione sed hominis adsumptione, profitentes et in forma Dei per naturam Divinam, et in forma servi ex conceptione Spiritus sancti secundum habitum hominis repertum fuisse"; X 19, SCh 462, 200: "Non alius filius hominis, quam qui Filius Dei est, neque alius in forma Dei, quam qui in forma servi perfectus homo natus est"; IX 14, SCh 462, 42: "Per sacramentum autem evangelicae dispensationis non alius est in forma servi quam qui in forma Dei est"; X 22, SCh 462, 202: "Et cum ipse ille filius hominis ipse sit qui et Filius Dei, quia totus hominis filius totus Dei Filius sit, quam ridicule praeter Dei Filium qui «verbum caro factum est», alium nescio quem tamquam profetam verbo Dei animatum praedicabimus, cum Dominus Iesus Christus et hominis filius et Dei Filius sit!"; IX 11, SCh 462, 36; IX 14, SCh 462, 40-42; IX 40, SCh 462, 96; X 19, SCh 462, 200; X 22, SCh 462, 202; X 63-66, SCh 462, 274-280.

${ }^{151} \mathrm{Cf}$. for example ibidem X 16, SCh 462, 196: "Hinc igitur maximum illud ac pulcherrimum suscepti hominis sacramentum Dominus ipse ostendit dicens: «Nemo ascendit in caelum, nisi qui de caelo descendit, filius hominis qui est in caelo»"; X 65, SCh 462, 278. 
Incarnation is both God and man ${ }^{152}$. Thus, it shows a colossal and an irreconcilable difference of his and Photinus's Christology. In such manner, actually, by virtue of the hypostatic union the Son of God, God the Word could have suffered and died, and not in his Divine nature as it was thought by Arians, nor it was a mere man that suffered on the cross, as it was thought by Photinus, or as Arians see the pro-Nicene Christ ${ }^{153}$ :

"The understanding (intellegentia) of the Divine mystery consists of this, to recognize Him as man whom you recognize as God; not to divide [non dividere] Jesus Christ because the Word was made flesh (cf. Jn 1, 14), not to believe that He was buried of whom you know that He rose from the dead, not to doubt that He whose burial you do not dare to deny rose from the dead" 154 .

Precisely here originated Hilary's criticism, and according to our opinion, the efforts to distance himself from Photinus's Christology and his idea of the "Incarnation", which does not open the possibility that Divine person can truly become a human. As it was seen, it perhaps involves also the origin of Christ's humanity that is in all of its dimensions communis, which has significant consequences. This standpoint did not have to be Photinus's, but however, it could have been attributed to Pro-Nicene Christology only on the basis of a pure fact that it held Christ's human nature as complete. The origin of Christ's body and particularly of his soul, for Hilary can be found in a spiritual conception ${ }^{155}$. Becoming man, as it was shown, the pre-existent (true) Son of God, Christ, the Word, by himself (ex se) assumes (takes on, appropriates) to himself human

${ }^{152}$ Cf. ibidem X 22, SCh 462, 204: "Natus autem est, non ut esset alius adque alius, sed ut ante hominem Deus, suscipiens hominem, homo Deus posset intellegi".

${ }^{153}$ Cf. ibidem IX 11, SCh 462, 36: "Intellegisne hunc triumfantem potestates in semetipso? Sentisne quod a se non differat caro spoliata et carne se spolians? In semetipso enim triumfat, id est in ea qua se carne spoliavit. Videsne ita Deum et hominem paedicari, ut mors homini. Deo vero carnis excitatio deputetur, non tamen ut alius sit qui mortus est, et alius sit per quem mortuus resurgit? Spoliata enim caro Christus est mortuus, et rursum Christum a mortuis excitans idem Christus est carne se spolians. Naturam Dei in virtute resurrectionis intellege, dispensationem hominis in morte cognosce. Et cum sint utraque suis gesta naturis, unum tamen Christum Iesum eum memento esse qui utrumque est"; IX 10, SCh 462, 34: "Christus enim mortus est carne se spolians. Tene ergo Christum hominem a Deo ex mortuis excitatum, tene Deum Christum salutis nostrae operationes cum esset moriturus operantem. Vt cum haec Deus operatur in Christo, operans licet Deus, spolians se tamen Christus carne moriturus sit; et cum mortuus est Christus, operans ante mortem Deus, mortuum tamen Christum operatio Dei excitet: cum ipse sit Christum a mortuis excitans qui est ante mortem Christus operatus, et idem sit spolians se carne moriturus"; X 22, SCh 462, 204: "Itaque cum Iesus Christus et natus et passus et mortuus et sepultus sit, et resurrexit".

${ }^{154}$ Ibidem X 60, SCh 462, 270: "Sed sacramenti istud divini intellegentia est, non ignorare Deum, quem non nescias hominem; non nescire autem hominem, quem non ignores Deum; Christum Iesum non dividere, «quia verbum caro factum est»; sepultum non putare, quem resuscitasse intellegas; suscitasse non ambigere, quem negare non audeas non sepultum”, transl. McKenna, p. 446.

${ }^{155}$ Cf. ibidem X 21, SCh 462, 202: "spiritalis conceptionis sacramentum"; II 24, SCh 443, 314; X 44, SCh 462, 240-242; II 26, SCh 443, 318. 
nature - single, specific, complete human nature - body and soul ${ }^{156}$. He does not just accidentally dwell in whole already conceived human as impersonal and non-subsistent God's word. The union of the pre-existent Divine person of Christ, Son of God, God the Word and the assumed human nature is, according to Hilary, physical, substantial ${ }^{157}$. Son of God, God the Word was indeed made man (and Photinus does not see it that way), one and the same ${ }^{158}$, both God and a man ${ }^{159}$. Due to his origin and to the unity of person, Jesus even as man would be sinless, so he could, among others, by suffering and bearing a punishment which was due to our sins, suffer for us, and be free of sinful human weakness and of defects of human suffering, with which Hilary is additionally protecting him from the Arian accusations for weakness of the Divine nature:

"He had a body, but a unique one which was of his own origin; He did not come into existence through the imperfections of a human conception, but subsisted in the form of our body by the power of His own divinity, for $\mathrm{He}$ truly represents us through the form of a slave, but $\mathrm{He}$ is free from the sins and the defects of a human body, so that we are indeed in Him by the birth from the Virgin, but our defects are not in Him because of the power of the origin that has proceeded from Him, while He who was born as a man, He was not born through the imperfections of a human conception. The Apostle clung to the mystery of this birth that was to be revealed when he said: «But he humbled himself, taking the nature of a slave, being made in the likeness of man, and in habit found as a man», so that by His assumption of the form of a slave we are to understand that $\mathrm{He}$ was born in the form of man, but, while He was made in the likeness of man and found in the habit as a man, the outward appearance and the true nature of the body bear testimony to the man, but $\mathrm{He}$ who was found in the habit as man does not have the defects of nature.

The birth is in the likeness of our nature, not in the appropriation of our defects. Because the nature of the birth seems to be indicated by the fact that $\mathrm{He}$ received the form of a slave, He added that $\mathrm{He}$ was made in the likeness of man and found in the habit as man in order that we might not imagine that a nature that has been weakened by defects is essential for a true birth,

${ }^{156}$ Cf. ibidem X 15, SCh 462, 194: "Nam quomodo Filius Dei hominis filius erit natus, vel manens in Dei forma formam servi acceperit, si non potente Dei verbo ex se et carnem intra virginem adsumere et carni animam tribuere"; X 22, SCh 462, 202.

${ }^{157}$ Cf. ibidem II 24, SCh 443, 314-316; X 44, SCh 462, 240-242; II 26, SCh 443, 318; VIII 13 17, SCh 448, 302-312; IX 7, SCh 462, 26-28; X 22, SCh 462, 204; IX 13, SCh 462, 40; IX 38, SCh 462, 90; IX 51, SCh 462, 120; IX 4, SCh 462, 20-22.

${ }^{158}$ Cf. ibidem X 20, SCh 462, 200: "Qui si intellegerent sacramentum carnis adsumptae, intellegerent et sacramentum eiusdem et hominis fili et Dei Fili. Quasi vero si tantum ex virgine adsumpsisset corpus, adsumpsisset quoque ex eadem et animam".

${ }^{159}$ Cf. ibidem IX 4, SCh 462, 20-22: "Mediator ipse in se ad salutem ecclesiae constitutus, et ipso illo inter Deum et homines mediatoris sacramento utrumque unus existens: dum ipse ex unitis in idipsum naturis naturae utriusque res eadem est". 
since a true birth is in the form of a slave and the likeness of nature is in Him who was found in the habit as a man. He Himself was truly born as a man by Himself from the Virgin, and was found in the likeness of a sinful flesh. And the Apostle bore witness to this fact when He said in his Epistle to the Romans: «For what was impossible to the Law, in that it was weak because of the flesh, God has sent his own Son in the likeness of a sinful flesh, and of sin he has condemned sin». His eternal appearance was not as if it were that of a man, but as that of a man, nor is that flesh the flesh of sin but the likeness of the flesh of sin, while the external appearance of flesh comes from the true nature of the birth, and the likeness of the flesh of sin is free from the imperfections of human suffering. Thus, the man Jesus Christ also possesses the true nature of the birth while $\mathrm{He}$ is a man, and sin is not proper to Him while He is Christ, because He who is man could not but be man since He was born, and He who is Christ could not have lost that which Christ is because He is Christ. Thus, while Christ Jesus is man, He who is man also possesses the birth of man, and He who is Christ is not subject to the sinful weakness of man"160.

To conclude presented thoughts, we think of the hypothesis (Simonetti, Hanson), if it is based on the Book Ten of De Trinitate, that Photinus insisted on wholeness of Christ's humanity, meaning the Christ's possession of the human soul, as well as a soteriological motivation of that insistence (Simonetti) can be relativized, or at least point out on the conditionality of that discourse. The debate of the wholeness of the humanity of Christ as seen by Photinus's would be

${ }^{160}$ Ibidem X 25, SCh 462, 210-212: "Habuit enim corpus, sed originis suae proprium; neque ex vitiis humanae conceptionis existens, sed in formam corporis nostri virtutis suae potestane subsistens; gerens quidem nos per formam servi, sed a peccatis et a vitiis humani corporis liber: ut nos quidem in eo per generationem virginis inessemus, sed nostra in eo per virtutem profectae ex se originis vitia non inessent, dum homo natus non vitiis humanae conceptionis est natus. Tenuit enim apostolus demonstrandae nativitatis nuius sacramentum, cum ait: «Sed humiliavit se formam servi accipiens, in similitudine hominis constitutus et habitu repertus ut homo»: dum «formam servi» accepit, natus esse in forma hominis intellegatur; dum autem «in similitudine hominis constitutus et habitu repertus ut homo» est, species quidem et veritas corporis hominem testetur, sed naturas uitiorum qui ut homo sit habitu repertus ignoret. In similitudine enim naturae, non vitiorum proprietate generatio est. Nam quia in eo quod formam servi accepit, nativitatis videbatur significata esse natura, subiecit «in similitudine hominus constitutum et habtiu ut homo repertum»: ne natiuitatis veritas naturae quoque per vitia infirmis proprietas crederetur, cum et in «forma» servi esset uera natiuitas, et in «habitu repertum ut hominem» esset similitudo naturae: ipse quidem per virginem ex se natus homo, eti in similitudine vitiosae peccatis carnis inuentus. Quod idipsum ad Romanos scribens testatus apostolus est, cum ait: «Quod enim inpossibile erat legi, in quo infirmabatur per carnem, Deus Filium suum misit in similitudinem carnis peccati, et de peccato condemnavit peccatum». Non fuit habitus ille tantum hominis, sed et ut hominis; neque caro illa caro peccati, sed similitudo carnis peccati: dum et habitus carnis in nativitatis est veritate, et similitudo carnis peccati a vitiis humanae passionis aliena est. Ita «homo Christus Iesus» et in veritate nativitatis est dum homo est, et non in peccati proprietate dum Christus est: quia et qui homo est non potuit non homo esse quod natus est, et qui Christus est non potuit amisse quod Christus est. Adque ita dum «homo Christus Iesus» est, habet et nativitatem hominis qui homo est, nec est in vitiosa hominis infirmitate qui Christus est". 
more initiated, if any, by a debate of his adversaries (each out of his own reason, be that Arian or Hilarian), than Photinus would insisted on it per se.

Review of the doctrine of Photinus of Sirmium, as interpreted in Hilary's work De Trinitate, is difficult since Hilary provides just the basic outline of his opponents' doctrines, tries to reduce all heresies to "one capital error" and names not his living opponents (Smulders). It is known that Photinus' error was primarily Christological, which is confirmed by Hilary's testimony in De Trinitate that the only beginning of Jesus Christ (the Son, the Word), is that when He begins to exist as a human being.

According to Hilary, for Photinus the subject of the Incarnation is God the Word/the Word of God. The relationship of the Word and the Father, according to Hilary's interpretation, Photinus defines through analogy between the Word and the speaker; for Photinus it is a mere word by its nature, the expression of thought and the announcement of the future realities. Referring to Hilary, Photinus' standpoint is based on a miscomprehension of Jn 1:1 "the Word was with God", which he understood as "the Word was in God". For the purpose of the Incarnation, the Word ultimately understood as a part of God's powers, extended in order to dwell in man who was conceived in Mary. This error could be related to the Anathemas no. 6 and no. 7 at the Sirmium Council in 351, which condemn a standpoint according to which the Substance of God extends and contracts (no. 6), and the one according to which, the Son is the substance of God extended. In addition, these Anathemas are related to heretical doctrine presented in Hilary's De synodis 45, according to which

"the Unborn God by expansion of His substance extended Himself as far as the holy Virgin, in order that this extension produced by the increase of His nature and assuming manhood might be called Son"161.

Finally, referring to Hilary, for Photinus the Word is just a part or one of God's powers and it does not actually distinguish from God. It is something always internum to God. Photinus' doctrine excludes originating of the Word/ the Son from the Father by (true) generation. Based on Hilary's interpretation, the Word of God as understood by Photinus is not endowed with subsistence nor existence, so God is ultimately solitary. It is a strict Monarchianism.

For Photinus' understanding of the conception of Jesus Christ in Mary, De Trinitate offers two possible interpretations. According to the first, the Virgin Mary conceived through the non-subsistent Word of God, therefore, by supernatural intervention. According to the second, possible understanding of

${ }^{161}$ Hilarius Pictaviensis, Liber de synodis seu de Fide orientalium 45, PL 10, 514C - 515A, NPNF Ser. II, vol. 9, 17. 
completely natural conception with all its consequences including Original sin is allowed.

According to Hilary's interpretation of Photinus' doctrine, for the purpose of Incarnation the Word of God/God the Word "assumes" ("takes on") whole man, the entire living person already conceived in Mary. This "assuming" of a man, "the Incarnation" of the Word is accomplished through the extention of the non-subsistant Word of God and its in/dwelling in that man.

Hilary claims that "the Incarnation", as understood by Photinus, results in two subjects. On the one hand, it is a mere common man who was born of Mary, and whose soul was his only vital and, as it seems, operative principle. On the other hand, it is the non-subsistent Word of God that dwells in the Man. Based on the text of De Trinitate and according to Photinus, the Word can not be attributed any novum after the Incarnation, from the ontological point of view.

According to De Trinitate, Photinus reduce the union of the Man who was born of Mary and non-subsistent Word of God (a part of God's powers) to temporary and accidental in/dwelling, taking up of the residence of the Word of God in the man, in a manner the Spirit (of prophecy) dwells in the prophets.

The effect of the dwelling of the Word of God in the man (or the dwelling itself) can be taken as prophetal inspiration or animation consisting of mere external strengthening of the man and empowering him for his and Divine activity, nevertheless, man's vital, and as it seems operative, principle is his soul.

The union of the Word and the man is only a temporary and accidental. Based on De Trinitate, "Divine Sonship" or filiation and "deification" of man born of Mary, according to Photinus, seems to be due to the fact that the nonsubsisting Word of God - a part of God's powers - dwells in him, inspiring or animating him by strengthening him and empowering him for divine activity.

According to De Trinitate, the Son, that is, Christ, or the Word of God, begins to exist or subsist only in time, with the birth of Mary. The Word, that is, the Son, Christ has no pre-existence and is not the co-Creator of the world. Photinus therefore relates him to time and denies His eternal generation. For Hilary, Photinus' position is clearly adoptionist: the man is assumed into the Son and into the God.

According to Hilary, in Photinus' doctrine there is no place for the real Incarnation of the true Son of God. Hilary's interpretation of Photinus' understanding of Jesus Christ, the Son, is that he is not the Word made flesh, nor he is one and the same both God and Man. For Hilary Jesus Christ or Son of God as Photinus understands him is just someone like a prophet (a man) inspired, that is empowered by a Word of God - a part of God's powers - for divine activity; ultimately, Hilary reduces him to a mere man, to a creature.

Taking into consideration the opinions expressed in the scholarship according to which Photinus, motivated by soteriology, insisted on the wholeness of Jesus' humanity, that is on the fact that he had a human soul - the opinions that are based on a single source being it the Book Ten of Hilary's De Trinitate 
- as well as Arian understanding of the pro-Nicene Christology and the actual circumstances in which such Christology was interpreted as Photinus' Adoptionism, it seems reasonable to hold that these opinions can be taken relatively and that on the basis of the Book Ten of De Trinitate Photinus insisted on the wholeness of the human nature of Jesus Christ, that is on the fact that he had a human soul, just to the extent that he held that he was a mere man (in whom the non-subsisting Word of God dwelt as a Spirit in a prophet).

\section{(Summary)}

This article aims to provide the comprehensive and systematic review of the doctrine of Photinus of Sirmium ( $\uparrow 376)$, based on the work of Hilary of Poitiers De Trinitate composed between 358 and 360.

Photinus error is primarily Christological. The first part of the article deals with Hilary's interpretation of Photinus'understanding of the subject of the Incarnation according to which God the Word/the Word of God was comprehended as a part or one of God's powers, a mere word, the expression of thought, which does not really differ from God, having no subsistence or existence, so that God is ultimately considered solitary. It is a strict Monarchianism.

The second part focuses on Photinus'understanding (based on De Trinitate) of what was "assumed" of the humanity by the Word of God for the purpose of Incarnation, and in which way. Two interpretations referring to Photinus'understanding of the conception of Jesus Christ in Mary, attribute it supernatural causes (the Virginal conception by the non-subsistent Word) and presumably quite natural causes. For the purpose of the Incarnation, the Word of God "assumes" ("takes on") the entire man, conceived in Mary. The "Incarnation", as such, is accomplished by the extension of the non-subsisting Word and its in/ dwelling in that man.

Based on De Trinitate, the third part deals with the effects of "the Incarnation" as it was understood by Photinus. Hilary concludes that it results in two subjects: on the one hand, it is solus communis generis homo who was born of Mary, and on the other hand, the non-subsistent Word of God that dwelt in that man. The union of the man born of Mary and the Word of God - a part of God's powers - is reduced, by Photinus and in Hilary's interpretation, to habitatio, temporary and accidental in/dwelling of the Word of God in the man in a manner the Spirit dwelt in prophets. The effect of the in/dwelling of the Word in a man born of Mary (or the dwelling itself) can be taken as prophetal inspiration, animation, consisting of mere external strengthening of the man and empowering him for his and Divine activity, nevertheless, man's vital and, and as it seems operative, principle is his soul.

Based on De Trinitate, Divine Sonship or filiation and "deification" of man born of Mary, according to Photinus, seems to be due to the fact that the nonsubsisting Word of God - a part of God's powers - dwells in him, inspiring or animating him by strengthening him and empowering him for divine activity. 
According to Hilary, Photinus denies pre-existence of the Word, that is, the Son, Christ so he cannot even be the co-Creator of the world. He becomes existent, that is, subsistent only through the Incarnation and birth of Mary. For Hilary, Photinus' adoptionist position is clear: the man is assumed into the Son and into the God.

According to Hilary, in Photinus' doctrine there is no place for the real Incarnation of the true Son of God. Hilary's interpretation of Photinus' understanding of Jesus Christ, the Son, is that he is not the Word made flesh, nor he is one and the same both God and Man. For Hilary Jesus Christ or Son of God as Photinus understands him is just someone like a prophet (a man) inspired, that is empowered by a Word of God dwelling in him - by a part of God's powers - for divine activity; ultimately, Hilary reduces him to a mere man, to a creature.

The fourth part points out that opinions expressed in the scholarship - based exclusively on the Book Ten of Hilary's De Trinitate - according to which Photinus, motivated by soteriology, insisted on the wholeness of Jesus' humanity that is on the fact that Jesus Christ had a human soul, should be taken relatively. To conclude, on the basis of Book Ten of De Trinitate Photinus insisted on the wholeness of the humanity of Jesus Christ, that is, on his possessing of the human soul, just to the extent which he held that he was a mere man (in whom the nonsubsistent Word of God dwelt as a Spirit in prophets).

\section{DOKTRYNA HERETYCKA FOTYNA Z SIRMIUM W DE TRINITATE HILAREGO Z POITIERS}

\section{(Streszczenie)}

Celem niniejszego artykułu jest dokonanie wszechstronnego i systematycznego zarysu doktryny Fotyna z Sirmium ( $\uparrow 376)$, w oparciu o traktat De Trinitate Hilarego z Poitiers, który powstał między 358 a 360 rokiem.

Błąd Fotyna tkwi przede wszystkim w chrystologii. Pierwsza część artykułu dotyczy interpretacji, jakiej dokonał Hilary odnośnie do doktryny Fotyna na temat wcielenia, zgodnie z którą Bóg Słowo / Słowo Boże było rozumiane jako część lub jeden z przymiotów Bożych, albo zwykłe słowo, czy ekspresja myśli, które $\mathrm{w}$ istocie nie różni się od Boga i nie posiada żadnego życia ani istnienia, tak że ostatecznie koncepcja ta twierdzi, że Bóg jest tylko sam. Jest to rygorystyczny monarchianizm.

Druga część koncentruje się na pojmowaniu przez Fotyna (na podstawie De Trinitate) tego, co i w jaki sposób Słowo Boże "przybrało" z człowieczeństwa w celu wcielenia. Pojmowanie poczęcia Jezusa Chrystusa w Maryi przez Fotyna szło w dwóch kierunkach: jeden zakładał nadnaturalne przyczyny (dziewicze poczęcie przez niesubstancjalne Słowo), drugi zaś przypuszczalnie zupełnie naturalne. W celu wcielenia Słowo Boże „przyjmuje” (,przybiera”) całego człowieka, poczętego z Maryi. „Wcielenie” jako takie jest więc zrealizowane poprzez rozszerzenie niesubstancjalnego Słowa i jego zamieszkanie w człowieku. 
Trzecia część, bazująca również na De Trinitate, omawia pojmowanie przez Fotyna skutków „wcielenia”. Hilary stwierdza, że wynika to z dwóch powodów: $\mathrm{z}$ jednej strony jest solus communis generis homo, zrodzony z Maryi, z drugiej zaś niesubstancjalne Słowo Boże, które zamieszkało w tym człowieku. Unia człowieka zrodzonego z Maryi i Słowa Bożego - części mocy Bożej - jest przez Fotyna (w interpretacji Hilarego) zredukowana do habitatio - czasowego i akcydentalnego zamieszkania Słowa Bożego w człowieku w taki sposób, w jaki Duch zamieszkiwał w prorokach. Skutek zamieszkania Słowa w człowieku zrodzonym z Maryi (lub samo mieszkanie) może być postrzegany jako prorocze natchnienie, ożywienie, polegające na zwykłym zewnętrznym umocnieniu człowieka, umożliwiającym mu jego Boskie działanie, chociaż, jak się wydaje, jego witalną i operatywną zasadą jest jego dusza.

Według Fotyna, Boskie Synostwo lub rodowód i „deifikacja” człowieka zrodzonego z Maryi wydaje się wynikać z faktu, że niesubstancjalne Słowo Boże - część mocy Bożej - mieszka w nim, pobudza lub ożywia go poprzez umocnienie i wlanie siły do prowadzenia Bożej działalności. Zdaniem Hilarego, Fotyn negował preegzystencję Słowa, to znaczy Syna, tak więc Chrystus nie może być jednocześnie współstwórcą świata. On staje się istniejący, tzn. substancjalny, tylko poprzez fakt wcielenia i narodzenia z Maryi. Dla Hilarego, stanowisko adopcjanistyczne Fotyna jest wyraźne: człowiek zostaje przyjęty na Syna i na Boga.

Według Hilarego, w doktrynie Fotyna nie ma miejsca na realne wcielenie prawdziwego Syna Bożego. Zdaniem Hilarego, Fotyn nie uważał Jezusa Chrystusa ani za Słowo, które stało się ciałem, ani też że jest On jeden i ten sam, zarówno Bogiem, jak i człowiekiem. W rozumieniu Fotyna Jezus Chrystus lub Syn Boży, jest kimś takim, jak natchniony prorok (człowiek), który jest umocniony przez Słowo Boże, zamieszkujące w Nim jako element mocy Bożej, w celu Bożego działania. Ostatecznie, według Hilarego, Fotyn redukuje go do zwykłego człowieka, do stworzenia.

W czwartej cześci artykułu autorzy pokazują, że opinie formułowane przez naukowców, bazujące wyłącznie na $\mathrm{X}$ księdze De Trinitate Hilarego, zgodnie z którą Fotyn, motywowany przez soteriologię, podkreślał pełnię człowieczeństwa Chrystusa, to jest fakt, że Jezus Chrystus miał ludzką duszę, należy traktować relatywnie. Podsumowując, na podstawie X księgi De Trinitate Hilarego, Fotyn podkreślał pełnię człowieczeństwa Jezusa Chrystusa, czyli posiadanie przez Niego duszy ludzkiej tylko w takim zakresie, w jakim uznał, że był on zwyczajnym człowiekiem (w którym niesubstancjalne Słowo Boże mieszkało podobnie jak Duch w prorokach).

Key words: Photinus of Sirmium, Hilary of Poitiers, De Trinitate, monarchianism, adoptionism.

Slowa kluczowe: Fotyn z Sirmium, Hilary z Poitiers, De Trinitate, monarchianizm, adopcjanizm. 


\section{BIBLIOGRAPHY}

\section{Sources}

Concilium Sirmiense (351) Anathematismi, ed. in: SCL 1, Kraków 2006, 202-205.

Epiphanius, Panarion, PG 41-43, transl. F. Williams: The Panarion of Epiphanius of Salamis, Books II and III. De Fide, Leiden - Boston $2013^{2}$.

Hilarius Pictaviensis, De Trinitate, I, ed. J. Doignon - G.M. de Durand - Ch. Morel - G. Pelland, SCh 443, Paris 1999; II, ed. J. Doignon - G.M. de Durand - Ch. Morel - G. Pelland, SCh 448, Paris 2000; III, ed. G.M. de Durand - Ch. Morel - G. Pelland, SCh 462, Paris 2001; transl. S. Mc Kenna: Saint Hilary of Poitiers, The Trinity, The Fathers of the Church 25, New York 1954.

Hilarius Pictaviensis, Liber de synodis seu de fide orientalium, PL 10, 479-546, transl. E.W. Watson - L. Pullan - K. Knight, in: St. Hilary of Poitiers, On the Councils, ed. P. Schaff - H. Wace, NPNF Ser. II, vol. 9, Buffalo (NY) 1899, 4-29.

\section{Literature}

Bardy G., Photin de Sirmium, DThC XII/2 1532-1536.

Bескwiтн Ch., Hilary of Poitiers on the Trinity. From "De Fide" to "De Trinitate", New York 2008.

Brennecke H.C., Hilarius von Poitiers, TRE XIV 315-322.

Durst M., Hilarius, hl., v. Poitiers, LThK V 100-102.

Grillmeier A., Christ in Christian Tradition, I, transl. J. Bowden, Atlanta $1975^{2}$.

Grillmeier A., Gesù il Cristo nella fede della Chiesa, I/1, Brescia 1982.

Hanson R.P.C., The Arian Doctrine of the Incarnation, in: Arianism: Historical and Theological Reassessments, ed. R.C. Gregg, Cambridge (MA) 1985, 181-211.

Hanson R.P.C., The Search for the Christian Doctrine of God. The Arian Controversy (318-386), Grand Rapids (MI) 2007².

Kelly J.N.D., Early Christian Creeds, London $1976^{3}$.

Moreschini C., Il linguaggio teologico di Hilario di Poitiers, SC 103 (1975) 339-375.

Simonetti M., Fotino di Sirmio, NDPAC II 1998-1999.

Simonetti M., Studi sull'arianesimo, Rome 1965.

SMulders P., La Doctrine trinitaire de S. Hilaire de Poitiers, Rome 1944.

Speller L.A., New Light on the Phoitinians: the Evidence of Ambrosiaster, ThS 34 (1983) 99-113.

Williams D.H., Monarchianism and Photinus of Sirmium as the Persistent Heretical Face of the Fourth Century, HTR 99 (2006) 187-206. 